\title{
Ionic Currents of Drosophila Neurons in Embryonic Cultures
}

\author{
Lou Byerly and Hung-Tat Leung \\ Neurobiology Section, Department of Biological Sciences, University of Southern California, Los Angeles, California 90089
}

\begin{abstract}
Drosophila offers a unique opportunity to determine how the genome codes for ionic channels in an organized nervous system. Considerable progress has already been made in studying the molecular biology of Drosophila K channels. In order for similar progress to be made on neuronal voltagedependent $\mathrm{Ca}$ channels, a physiological preparation is needed in which the function of these channels can be directly studied. The patch-clamp studies reported here show that cultures of embryonic Drosophila cells (Seecof and Unanue, 1968) meet this need. These cultures provide the first opportunity to study with voltage-clamp techniques the $\mathrm{Ca}$ and Na currents of Drosophila neurons. The focus of these studies is on the Ca current; however, descriptions of the $\mathrm{K}$ and $\mathrm{Na}$ currents are also given since they help to characterize the cells studied and the quality of the voltage clamp.

The voltage-dependent $\mathrm{K}, \mathrm{Na}$, and $\mathrm{Ca}$ currents of Drosophila neurons are very similar to those of molluscan neurons and other better studied neurons. The $K$ currents are the largest currents in these neurons, averaging over $\mathbf{3 0 0}$ PA at $+20 \mathrm{mV}$. There are 2 classes of $\mathrm{Ca}$-independent $\mathrm{K}$ currents, inactivating currents that are 4-AP sensitive, and noninactivating currents that are insensitive to 4-AP. A large fraction of the $K$ currents are located in the somal membrane. The Na currents are TTX sensitive and probably located in the processes. The peak amplitudes of the Ca currents vary from 0 to over $100 \mathrm{pA}$ in these neurons, averaging $40 \mathrm{pA}$. With $5 \mathrm{~mm}$ external $\mathrm{Ca}^{2+}$ or $\mathrm{Ba}^{2+}$, the $\mathrm{Ba}$ currents are about twice as large as the Ca currents. Although $100 \mu \mathrm{M} \mathrm{Cd^{2+ }}$ completely blocks the $\mathrm{Ca}$ current, organic blockers have very little effect. Variable inactivation characteristics and sensitivity to washout suggest the possibility of multiple types of Ca channels. A search for single-channel Ba currents in the somal membrane was unsuccessful.
\end{abstract}

The fruit fly Drosophila provides unique opportunities to study how genes code for a nervous system. Drosophila both has an organized nervous system and a well-studied, easily manipulable genome. A number of laboratories have focused on how genes control the properties of excitable membranes in Drosophila; these approaches have been reviewed recently (Ganetzky and Wu, 1985; Jan et al., 1985; Salkoff and Tanouye,

\footnotetext{
Received Feb. 7, 1988; revised Apr. 4, 1988; accepted Apr. 4, 1988.

We wish to thank Paul Salvaterra, Nicole Bournias-Vardiabasis, and Tina Nair for introducing us to the embryonic Drosophila cultures and for extensive instruction in growing them. Also we are indebted to Maria Pellegrini who has generously shared her fly populations with us. This work was supported by NIH Grant NS 15341 and by an NIH Research Career Development Award (NS 00797).

Correspondence should be addressed to Lou Byerly at the above address. Copyright (C) 1988 Society for Neuroscience $0270-6474 / 88 / 114379-15 \$ 02.00 / 0$
}

1986). The genetic analysis of ionic channels has progressed the furthest with $\mathrm{K}$ channels, especially the A type $\mathrm{K}$ channel. Many mutations that affect $K$ channels have becn studicd, and the region of the $\mathrm{X}$ chromosome coding for the $\mathrm{A}$ channel has been cloned (Baumann et al., 1987; Kamb et al., 1987; Papazian et al., 1987). Also a number of mutants thought to affect Na channels have been studied, but to date no Ca channel mutants have been identified.

Our laboratory has been studying the control of Ca currents by intracellular messengers such as $\mathrm{Ca}^{2+}$ and cyclic nucleotides. This problem is complicated by the diversity of Ca channels and the number of different mechanisms that control different types of Ca channels (Byerly and Hagiwara, 1988). The direct study of these control mechanisms is greatly limited by the labile nature of most $\mathrm{Ca}$ channels. Ca currents disappear (or "washout") when the intracellular side of the membrane is directly exposed to artificial solutions (Kostyuk et al., 1981; Byerly and Hagiwara, 1982; Fenwick et al., 1982). Drosophila seems a promising system in which to pursue this problem. It should be possible to determine the distinct genes coding for Ca channels and the genes coding for pumps, receptor proteins, kinases, and other proteins that modulate the function of $\mathrm{Ca}$ channels.

We have chosen to use the embryonic cell cultures developed by Seecof and colleagues (Seecof and Unanue, 1968; Seecof et al., 1971, 1973; Salvaterra et al., 1987) for these studies of $\mathrm{Ca}$ currents because robust $\mathrm{Ca}$ currents are present in both the neurons and myocytes of these cultures. Since gigaohm seals form readily on these cells, patch-clamp techniques (Hamill et al., 1981) can be used to study both whole-cell and single-channel currents. Another important advantage of these cultures is that they can be made from lethal mutant embryos, permitting the study of large deletions in the genome. Since we were the first to do voltage-clamp studies on these embryonic cultures, we began by characterizing the whole-cell currents of the embryonic neurons. These studies are done on neurons with processes containing voltage-dependent channels, so the results are of limited biophysical value. However, it is possible to reach many qualitative conclusions about the ionic currents, and a sufficiently detailed description is provided to serve as reference in screening behavioral mutants for ones that affect membrane currents. Preliminary reports of this research have been published (Byerly, 1985, 1986; Leung and Byerly, 1987).

\section{Materials and Methods}

Preparation of cultures. The embryonic Drosophila cultures were prepared as described by Salvaterra et al. (1987) with a few minor changes. Eggs were collected for a $2 \mathrm{hr}$ period from Drosophila melanogaster (Oregon R) flies maintained in population cages at $26^{\circ} \mathrm{C}$. The cells, obtained by dissociating the gastrulating embryos, were plated on untreated $10 \mathrm{~mm}$ round glass coverslips (Bellco Biotechnology, Vineland, $\mathrm{NJ}$ ) in a $35 \mathrm{~mm}$ tissue culture dish at $4 \times 10^{5}$ cells $/ \mathrm{ml}$ in $2 \mathrm{ml}$ of 
Table 1. Composition of solutions (in mM)

\begin{tabular}{|c|c|c|c|c|c|c|}
\hline External solutions & $\mathrm{Na}^{+}$ & $\mathrm{K}^{+}$ & $\mathrm{Cl}^{-}$ & $\mathrm{Ca}^{2+}$ & $\mathrm{Mg}^{2+}$ & Other \\
\hline Dros. saline & 130 & 6 & 151 & 5 & 5 & - \\
\hline $0 \mathrm{~K}$ Dros. saline & 130 & 0 & 151 & 5 & 5 & 7 Tris \\
\hline Tris Dros. saline & 0 & 0 & 151 & 5 & 5 & 147 Tris \\
\hline Ba Tris Dros. saline & 0 & 0 & 151 & 0 & 5 & 147 Tris, $5 \mathrm{Ba}^{2+}$ \\
\hline $0 \mathrm{Ca}$ Tris Dros. saline & 0 & 0 & 151 & 0 & 10 & 147 Tris \\
\hline High Ba saline & 0 & 0 & 214 & 0 & 0 & $107 \mathrm{Ba}^{2+}, 5$ Tris \\
\hline $6 \mathrm{~K} / 5 \mathrm{Ca}$ Tris Dros. salinc & 0 & 6 & 151 & 5 & 5 & 140 Tris \\
\hline $6 \mathrm{~K} / 0 \mathrm{Ca}$ Tris Dros. saline & 0 & 6 & 151 & 0 & 10 & 140 Tris \\
\hline $60 \mathrm{~K} / 0 \mathrm{Ca}$ Tris Dros. saline & 0 & 60 & 151 & 0 & 10 & 80 Tris \\
\hline Internal solutions & $\mathbf{K}^{+}$ & $\mathrm{Cs}^{+}$ & $\mathrm{Cl}^{-}$ & $\mathrm{Asp}^{-}$ & $\mathrm{F}^{-}$ & \\
\hline $\mathrm{KCl}$ & 158 & 0 & 147 & 0 & 0 & \\
\hline KAsp & 156 & 0 & 6 & 139 & 0 & \\
\hline $\mathrm{CsCl}$ & 0 & 158 & 147 & 0 & 0 & \\
\hline CsAsp & 0 & 156 & 6 & 139 & 0 & \\
\hline $\mathrm{CsF}$ & 0 & 158 & 75 & 0 & 72 & \\
\hline
\end{tabular}

All external solutions contained $10 \mathrm{~mm}$ glucose and $10 \mathrm{~mm}$ HEPES (pH 7.4). All internal solutions, contained $5 \mathrm{~mm}$ EGTA, $0.5 \mathrm{mM} \mathrm{Ca}^{2+}, 1.0 \mathrm{~mm} \mathrm{Mg}^{2+}$, and $10 \mathrm{~mm}$ HEPES (pH 7.3).

medium. The cells were cultured in a dry-air incubator at $25^{\circ} \mathrm{C}$ for periods of $16 \mathrm{hr}-7 \mathrm{~d}$. Individual coverslips of cells were transferred to a small recording chamber $(<1.0 \mathrm{ml} \mathrm{vol})$ on the stage of an inverted microscope, where the cells were viewed by Hoffman differential interference optics.

Patch-clamp techniques. The cultured neurons were studied by wholecell and cell-attached patch-clamp configurations (Hamill et al., 1981). For whole-cell experiments the electrodes were pulled from $100 \mu \mathrm{l}$ VWR micropipets (VWR, Cerritos, CA), coated with Sylgard resin, and polished to a bubble number of 3.0-4.0 (Corey and Stevens, 1983). When filled with the standard CsAsp or KAsp internal solutions, these pipets had a resistance of 5-10 M $\Omega$. For ccll-attached patch recordings, the electrodes were pulled from thick-walled Corning 7052 glass tubing (Garner Glass, Claremont, CA). Most procedures were standard for whole-cell recording; however, we found that a special procedure described by Holton and Hudspeth (1986) had to be followed to obtain a stable seal when the pipet contained aspartate as the major anion. The tip of the electrode was soaked for a few seconds in a $1 \mathrm{~mm}$ streptomycin sulfate (Calbiochem) internal solution and then backfilled with standard internal solution (no streptomycin). This procedure proved indispensable for whole-cell studies which used aspartate for the internal anion. External solutions flowed directly onto the cell being studied from a 0.5 $\mathrm{mm}$ (inner diameter) tube that was positioned about $0.5 \mathrm{~mm}$ from the cell by a micromanipulator. During studies, the neural processes were attached to the glass coverslip, but the cell body was usually lifted a few micrometers above the glass surface.

Since the neurons studied do have processes, the quality of the wholecell voltage clamp depends on the location of the channels that carry the current of interest. A study of the capacitive transient elicited by a hyperpolarizing voltage step provides information relevant to the quality of the voltage clamp. Figure 1 (lower right) shows the capacitive transients elicited by $50 \mathrm{mV}$ hyperpolarizing voltage steps applied to 3 different cells. In general, the capacitive transients have a complicated time course, which we have approximated by a double-exponential form. The faster-decaying component has a time constant of $330 \pm 150$ $\mu \sec ($ mean $\pm \mathrm{SD}, n=37$ ), and the slower-decaying component has a time constant of $1.1 \pm 0.4 \mathrm{msec}$. We assume that the fast component corresponds to charging of the somal membrane and near regions of larger processes, while the slow component results from charging of more distal regions of the processes. By integrating separately the fast and slow capacitive currents, it is possible to calculate the capacitance that is charged at each rate. The fast component has a capacitance of $3.0 \pm 1.0 \mathrm{pF}$; this is larger than the $1.1 \mathrm{pF}$ capacilance expected for a spherical membrane of $6 \mu \mathrm{m}$ diameter and $1 \mu \mathrm{F} / \mathrm{cm}^{2}$ specific capacitance. The associated series resistance is calculated to be $120 \pm 60 \mathrm{M} \Omega$, an order of magnitude larger than the measured pipet tip resistance before obtaining a seal. This calculated series resistance is an upper limit to the series resistance of the patch electrode during the whole-cell recording. Since this fast component of the capacitive transient includes current that charges regions of the processes that are close to the soma, the calculated resistance will contain a contribution from the longitudinal resistance of the processes. In a few cells the slope conductance for $\mathrm{K}$ current-voltage relation became greater than the reciprocal of the series resistance calculated from the fast component of the capacitive transient, e.g., in one cell the calculated series resistance was $240 \mathrm{M} \Omega$, but the $\mathrm{K}$ current-voltage slope conductance was $1 /(80 \mathrm{M} \Omega)$. This shows that the $\mathrm{K}$ current of these cells sees less resistance than the calculated series resistance; in the example given, the patch electrode series resistance must be less than $80 \mathrm{M} \Omega$. The patch electrode series resistance during whole-cell recordings may be no more than 2 or 3 times the electrode resistance measured before seal formation $(5-10 \mathrm{M} \Omega)$, as is usually assumed for whole-cell patch-clamp recordings. As is illustrated in Figure 1, the amplitude of the slow component of the capacitive transient varies considerably from cell to cell. The capacitance charged at the slower rate is $2.6 \pm 1.5 \mathrm{pF}(n=37)$, and the calculated associated series resistance is $500 \pm 200 \mathrm{M} \Omega$. The voltage error for a $100 \mathrm{pA}$ current is probably less than $3 \mathrm{mV}$ if the channels reside in the soma but more than $50 \mathrm{mV}$ if the channels are located distally.

Solutions. The composition of the external and internal solutions used are given in Table 1 . The external solutions had a higher $\mathrm{Ca}^{2+}$ concentration than standard Drosophila salines previously used (Jan and Jan, 1976; Salkoff and Wyman, 1983a) in order to increase the magnitude of Ca currents. Tris was used as a nonpermeant substitute for $\mathrm{Na}^{+}$and $\mathrm{K}^{+}$. The external $\mathrm{pH}$ was buffered by $10 \mathrm{~mm}$ HEPES; solutions were titrated with $\mathrm{NaOH}$ or TrisOH to $\mathrm{pH}$ 7.4. All external solutions had an osmolarity close to 280 mOsm. TEA chloride and 4 -aminopyridine (4-AP) were added to external solutions without adjusting osmolarity, but $\mathrm{pH}$ was adjusted after these additions. TTX, nifedipine, verapamil, W-7 [ $N$-(6-aminohexyl)-5-chloro-1-napthalenesulfonamide], and diltiazem were obtained from Sigma Chemical Co. D-600 (gallopamil hydrochloride) was provided by Knoll AG, and BAY K8644 was provided by Dr. Scriabine of Miles Pharmaceuticals. Nifedipine, BAY K8644, diltiazem, verapamil, D-600, and W-7 were kept in dark containers and used under minimal light conditions. Stock solutions were made of these drugs in ethanol. The final concentration of ethanol in the solutions applied to the cells was always less than $0.4 \%$ and had no effect itself on the ionic currents.

The internal solutions had $\mathrm{Ca}^{2+}$ buffered to very low levels by $5 \mathrm{~mm}$ EGTA with $0.5 \mathrm{~mm}$ added $\mathrm{Ca}^{2+}$. Internal $\mathrm{pH}$ was buffered by $10 \mathrm{~mm}$ HEPES; the final $\mathrm{pH}$ was adjusted to 7.3 by addition of $\mathrm{KOH}$ or $\mathrm{CsOH}$. $\mathrm{Cs}^{+}$was used as a nonpermeant replacement for $\mathrm{K}^{+}$. Often the internal solutions were "enriched" by the addition of $2 \mathrm{~mm}$ adenosine 5 '-triphosphate (ATP), $100 \mu \mathrm{M}$ dibutyryl cAMP, and $2 \mathrm{mM}$ theophylline (Sigma). These enrichments were only added to the solution with which 

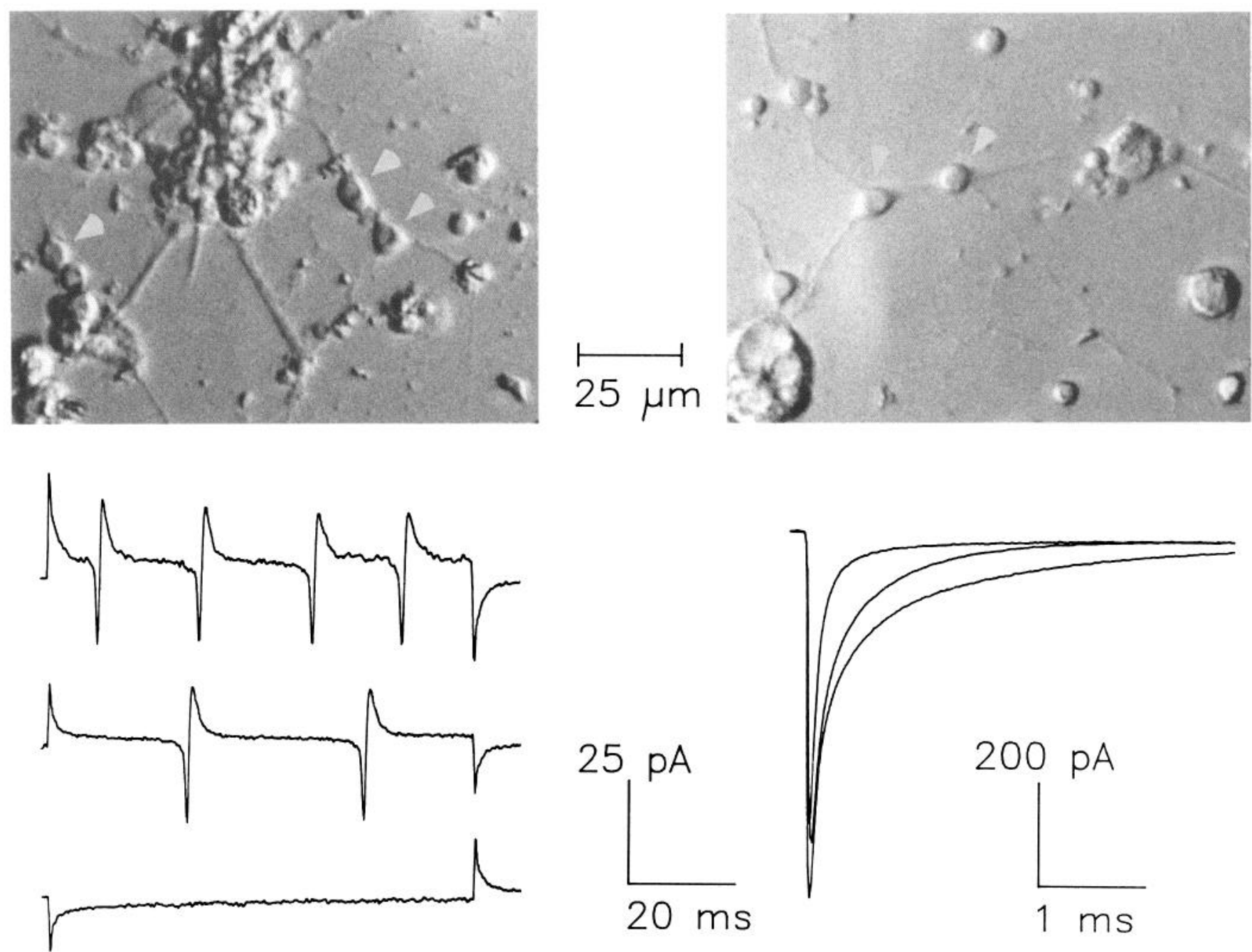

Figure 1. General properties of neurons studied. Top, Photographs of Drosophila embryonic cultures, using Hoffman differential interference optics. Arrowheads indicate cells of the type studied. These cells have diameters of 4-8 $\mu \mathrm{m}$. Bottom left, Action potential currents recorded in cellattached patch. Pipet was held at $-73 \mathrm{mV}$. Pipet was stepped to $-113 \mathrm{mV}$ in lower trace, $-33 \mathrm{mV}$ in middle trace, and $+7 \mathrm{mV}$ in upper trace (cell 5/28/6-7). Bottom right, Capacitive transients recorded in whole-cell mode when pipet was stepped $50 \mathrm{mV}$ below holding potential. Pipet capacitive transients, recorded from cell-attached patch, have been subtracted. Transients for 3 different cells are shown, illustrating fast and slow transients. Records were filtered at $5 \mathrm{kHz}$. By fitting a double-exponential function to the transients, a fast time constant, $\tau_{\mathrm{F}}$, and capacitance, $C_{\mathrm{F}}$, and slow time constant, $\tau_{\mathrm{S}}$, and capacitance, $C_{\mathrm{S}}$, are determined. Cell 7/15/7-36: $\tau_{\mathrm{F}}=90 \mu \mathrm{sec}, C_{\mathrm{F}}=1.5 \mathrm{pfd}, \tau_{\mathrm{S}}=480 \mu \mathrm{sec}, C_{\mathrm{s}}=0.6 \mathrm{pfd} ;$ cell $6 / 26 /$ $7-14: \tau_{\mathrm{F}}=220 \mu \mathrm{sec}, C_{\mathrm{F}}=3.3 \mathrm{pfd}, \tau_{\mathrm{S}}=400 \mu \mathrm{sec}, C_{\mathrm{S}}=0.8 \mathrm{pfd}$; cell $6 / 30 / 7-3: \tau_{\mathrm{F}}=500 \mu \mathrm{sec}, C_{\mathrm{F}}=2.0 \mathrm{pfd}, \tau_{\mathrm{S}}=2.2 \mathrm{msec}, C_{\mathrm{S}}=3.6 \mathrm{pfd}$.

the pipet was backfilled; they were not added to the solution in which the tip was initially soaked (for $10 \mathrm{sec}$ ) out of concern that they might interfere with seal formation. Cells tended to swell slowly during wholecell studies using the concentrations given in Table 1. It was found that diluting these internal solutions with distilled water to $90 \%$ of given concentrations prevented swelling. This dilution was used in some experiments for which longer recording times were necessary and the exact concentrations of internal ions was not critical.

Data handling. Experiments were performed with 2 different patchclamp amplifiers, a Dagan 8900 (Dagan, Minneapolis, MN) and an Axopatch 1A (Axon Inst., Burlingame, CA). Test protocol generation, data acquisition, and analysis were done with the pCLAMP system (Axon Inst.) on an IBM-AT personal computer. All membrane potentials were corrected for the liquid-junction potentials as described by Hagiwara and Ohmori (1982). Liquid-junction potentials were measured using a $3 \mathrm{M} \mathrm{KCl}$ reference electrode; measured values were -4.5 $\mathrm{mV}$ for $\mathrm{KCl} / \mathrm{Dros}$. saline, $-10.5 \mathrm{mV}$ for KAsp/Dros. saline, and +3 $\mathrm{mV}$ Tris Dros. saline/Dros. saline. No series resistance compensation was used in the voltage-clamp studies. Current records were low-pass filtered (4 pole) at $1 \mathrm{kHz}$ except as indicated. Records were digitized at intervals varying from $20 \mu \mathrm{sec}$ to $2 \mathrm{msec}$. Leakage currents have not been subtracted from the current records shown in the figures, except for Figures 1 and 4 (where the subtractions are explained in the legends). Leakage currents are typically less than $20 \mathrm{pA}$; an example of leakage currents is given in Figure $9(0 \mathrm{Ca})$.

\section{Results}

\section{General properties of cells studied}

Since these embryonic cultures contain several cell types, including muscle and other non-neuronal types, it is important to identify the cells chosen for study. Neurons were identified by the presence of one or more thin processes. Neurons with clearly visible cell bodies, usually alone or in small groups of $2-4$ cells, were selected for study. Neurons in larger clusters were not used for this study because preliminary studies suggested they have small Ca currents. The typical cell studied throughout this paper had 2 processes with an oval cell body $5-6 \mu \mathrm{m}$ in diameter. Occasionally, cells with only one process or with 3 processes were studied and were found to have very similar 

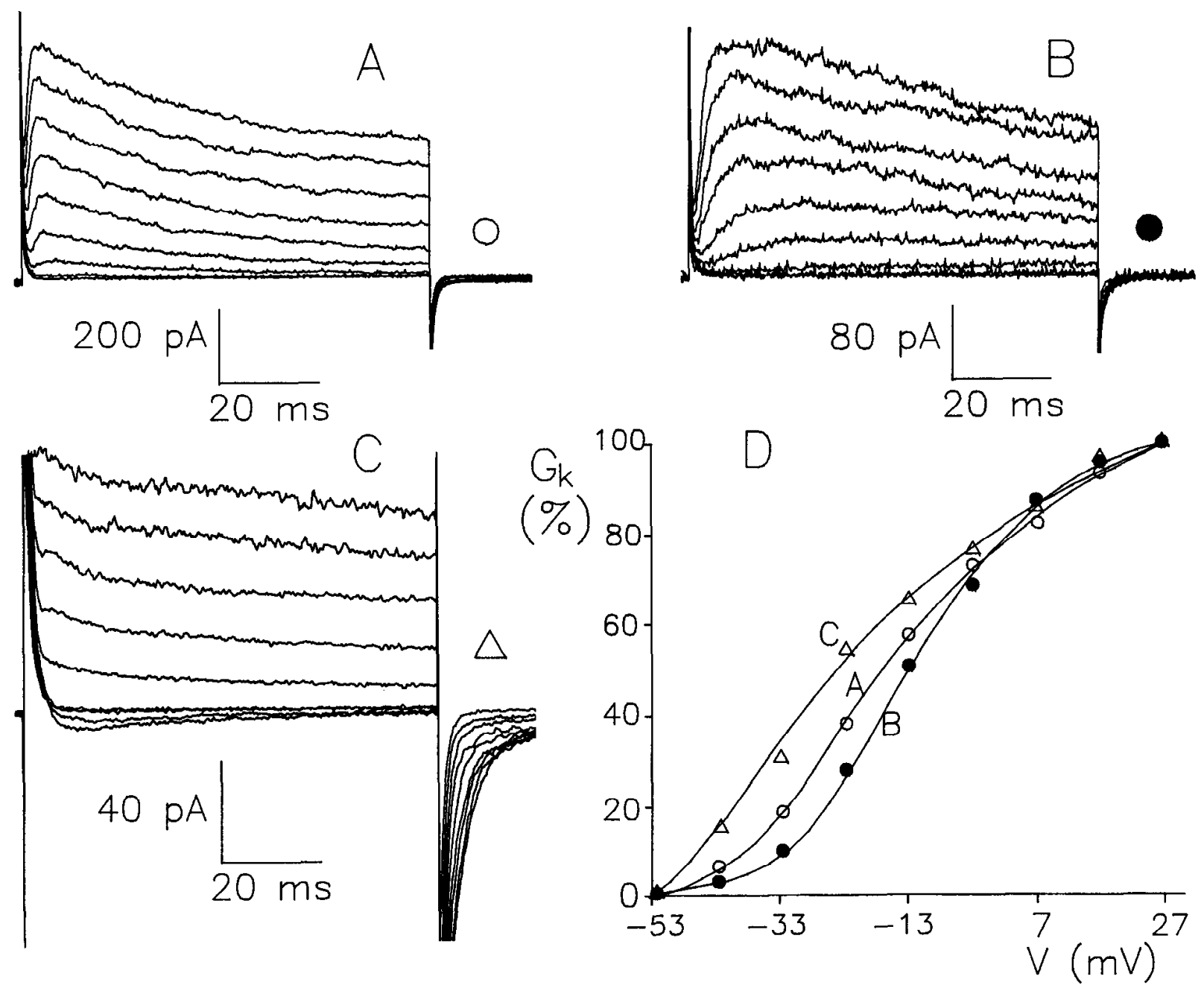

Figure 2. Activation of voltage-dependent $\mathrm{K}$ currents. $A-C, \mathrm{~K}$ currents recorded from 3 different cells in response to stepping the potential from the holding level of $-73 \mathrm{mV}$ to levels from $-53 \mathrm{mV}$ to $+27 \mathrm{mV}$ (intervals of $10 \mathrm{mV}$ ). External solution is $6 \mathrm{~K} / 0 \mathrm{Ca}$ Tris Dros. saline. Records filtered at $1 \mathrm{kHz}$. $A$ and $B$, Internal solution is KAsp plus $2 \mathrm{~mm}$ ATP; potential is returned to $-73 \mathrm{mV}$ near the end of each current record. Cells $7 / 15 / 7-50(A)$ and $7 / 15 / 7-37(B)$. C, Internal solution is $10 \% \mathrm{KAsp}$ and $90 \% \mathrm{CsAsp}$; inward $\mathrm{K}$ tail currents are recorded when potential is stepped down to $-53 \mathrm{mV}$ near the end of each current record (cell 12/15/7-7). D. Plots of normalized $\mathrm{K}$ conductance versus voltage for these 3 cells. $\mathrm{K}$ conductance is calculated for the cells of $A$ and $B$ by dividing the peak $\mathrm{K}$ current during each positive pulse by the driving force, assuming the reversal potential to be $-80 \mathrm{mV}$. Linear leakage conductance has been subtracted. $\mathrm{K}$ conductance for cell of $C$ is taken from the tail current measured $15 \mathrm{msec}$ after the step to $-53 \mathrm{mV}$.

membrane currents to the bipolar neurons usually studied. Examples of the types of cells studied are indicated by arrows in the photos of Figure 1. Cells were studied between 24 and 80 $\mathrm{hr}$ from the time of egg-laying $\left(25^{\circ} \mathrm{C}\right)$.

Most of the cells studied were capable of producing action potentials. The action potentials were detected as biphasic currents recorded from voltage-clamped, cell-attached patches. Action potentials occurred spontaneously in some cells and could be induced by polarizing the pipet in most cells. For the experiment shown in Figure 1 (lower left), the potential of the pipet was held at $-73 \mathrm{mV}$, which was approximately equal to the cell rcsting potential and drove little current into the cell. When the pipet potential was stepped $40 \mathrm{mV}$ more negatively (bottom trace), the cell was hyperpolarized and no action potentials occurred. When the pipet potential was stepped $40 \mathrm{mV}$ more positive than the holding level (middle trace), the cell was depolarized sufficiently to elicit repetitive action potentials. Stepping the pipet potential even more positive (top trace) elicited a higher frequency of action potentials. Presumably these action potential currents are capacitive currents, so their time course is proportional to the time derivative of the cell's membrane potential. The duration of the action potential, measured between the time of most rapid rise and time of most rapid fall, is only a few milliseconds. The amplitude of the action potential in the neuron cell body cannot be calculated since the area of the membrane patch is not known.

Aspartate was found to be the best anion to use in the intracellular solution during whole-cell experiments. With KAsp internal solution, the resting whole-cell resistance was $11.2 \pm 4.6$ $\mathrm{G} \Omega(n=14)$. With $\mathrm{KCl}$ internal solution, the resting resistance was lower, $5.1 \pm 2.7 \mathrm{G} \Omega(n=22)$, and the current recordings from these cells usually became very noisy in a few minutes. Fluoride was good as internal anion; it gave a high resting resistance and quiet current recording. However, Ca current disappeared within a few minutes when fluoride was the internal anion. 


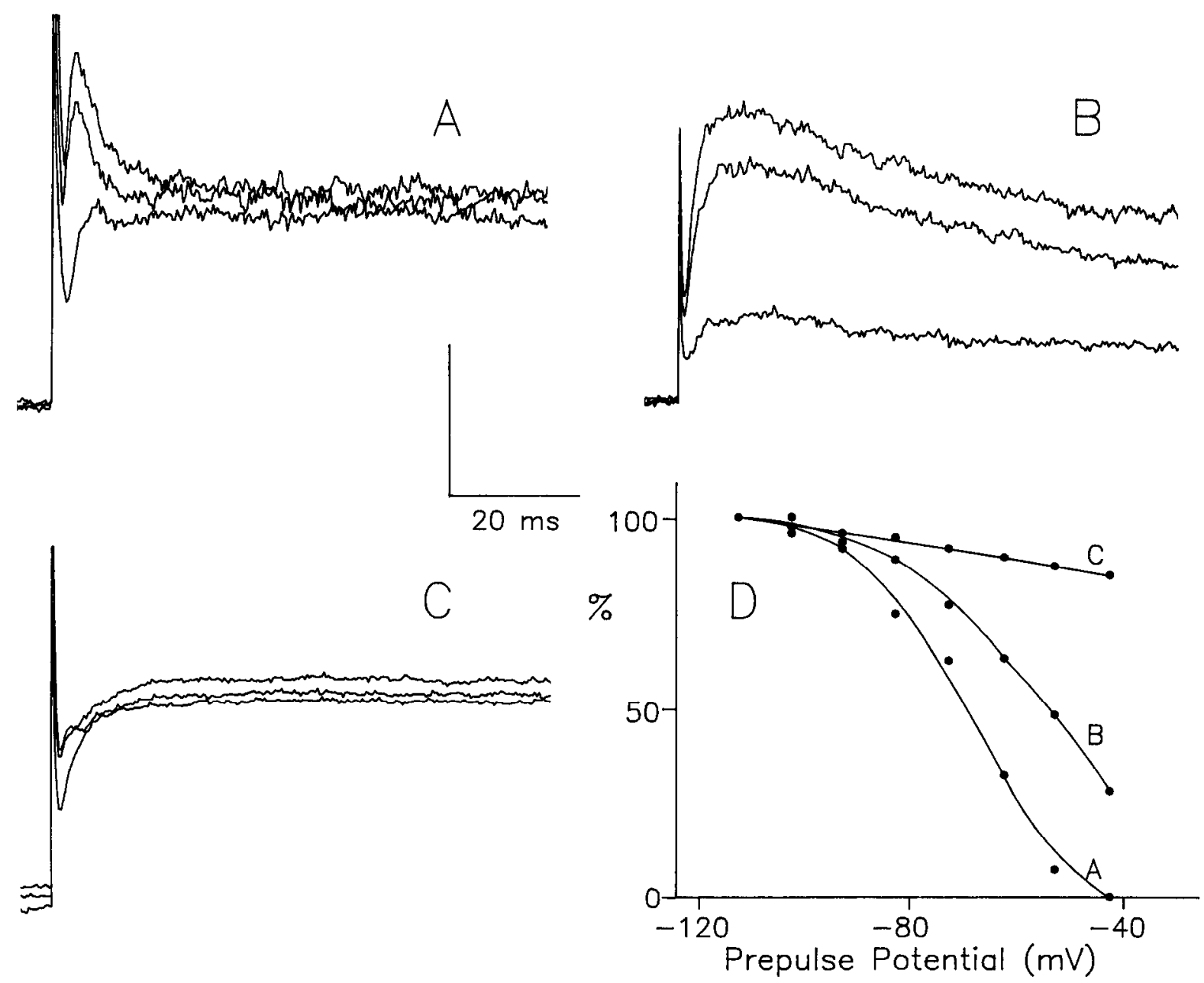

Figure 3. Steady-state inactivation of $\mathrm{K}$ currents. Currents recorded from 3 cells during pulses to $+17 \mathrm{mV}$ following $1 \mathrm{sec}$ prepulses to $-103 \mathrm{mV}$ (largest current), $-73 \mathrm{mV}$, and $-43 \mathrm{mV}$ (smallest current). Internal solution is KAsp plus $2 \mathrm{~mm}$ ATP; external solution is $6 \mathrm{~K} / 0$ Ca Tris Dros. saline. Current scale is $100 \mathrm{pA}$ for $A$ and $B, 200 \mathrm{pA}$ for $C$. $D$. Percentage of current activated on stepping to $+17 \mathrm{mV}$ is plotted against the potential of the prepulse; only the inactivating component is considered for $A$. Cells $7 / 10 / 7-34(A), 7 / 15 / 7-39(B)$, and 7/15/7-12 (C).

\section{Potassium currents}

The most prominent voltage-dependent currents in these Drosophila neurons are $\mathrm{K}$ currents. Figure $2, A$ and $B$, shows 2 examples of the $\mathrm{K}$ currents recorded with the normal intracellular $\mathrm{K}^{+}$concentration $(156 \mathrm{mM})$. In order to isolate $\mathrm{K}$ current from $\mathrm{Na}$ and $\mathrm{Ca}$ currents, the external solution contains no $\mathrm{Na}^{+}$ or $\mathrm{Ca}^{2+}$. The magnitude of the $\mathrm{K}$ currents measured at $+17 \mathrm{mV}$ in 14 neurons is $330 \pm 120 \mathrm{pA}$, the smallest $\mathrm{K}$ current being $190 \mathrm{pA}$ and the largest $570 \mathrm{pA}$. The average linear leakage current is only $8 \mathrm{pA}$ at $+17 \mathrm{mV}$. Because of the large size of the $K$ currents, the control of voltage may seriously fail during their measurement. However, if the $\mathrm{K}$ channels are primarily located in the soma and the patch-electrode series resistance is no more than 3 times the clcctrode resistance mcasured beforc seal formation, then the voltage-clamp error is less than $15 \mathrm{mV}$ for even the largest currents measured. The voltage dependence of the $\mathrm{K}$ conductance calculated for the currents shown in Figure 2, $A$ and $B$, is plotted in Figure $2 D$. Even though the $\mathrm{K}$ currents of the cell in Figure $2 A$ are almost 3 times larger than those of Figure $2 B$, the voltage dependence of the $\mathrm{K}$ conductance is nearly the same for the 2 cells. If, in fact, the $K$ currents of these 2 cells have the same voltage dependence for activation, this would suggest the voltage-clamp errors are not serious. As a further check against large escapes of the $\mathrm{K}$ current from voltage clamp, we measured the voltage dependence of the $\mathrm{K}$ conductance in cells clamped with electrodes containing $10 \%$ of the normal intracellular $\mathrm{K}^{+}$concentration. Figure $2 C$ shows the $\mathrm{K}$ currents from one of these cells. Even though the $K$ currents of these cells are inward at more negative values (the $K$ reversal potential is now near $-20 \mathrm{mV}$ ) and never larger than $100 \mathrm{pA}$, the $\mathrm{K}$ conductance (measured from the tail currents and plotted in Fig. $2 D$ ) has a similar voltage dependence as was measured for cells with the normal intracellular $\mathrm{K}^{+}$concentration.

The inactivation of the $\mathrm{K}$ currents suggests that there are at least 2 different types of $\mathrm{K}$ currents in these neurons. The total $\mathrm{K}$ current of most cells is slowly inactivating (Figs. 2, 3B), but in a minority of cclls the total $\mathrm{K}$ current does not inactivate (Fig. $3 C$ ) or a component inactivates much more rapidly (Fig. $3 A$ ). Figure 3 shows the $\mathrm{K}$ currents evoked in 3 cells by pulses to $+17 \mathrm{mV}$ after holding each cell at $-103,-73$, and $-43 \mathrm{mV}$ for $1 \mathrm{sec}$. Note that the leakage currents, which can be estimated from the currents at -103 and $-43 \mathrm{mV}$, are always less than $10 \%$ of the total noninactivating current at $+17 \mathrm{mV}$. As shown by the plots in Figure $3 D$, the magnitude of the noninactivating $\mathrm{K}$ current is almost insensitive to the holding potential, while 

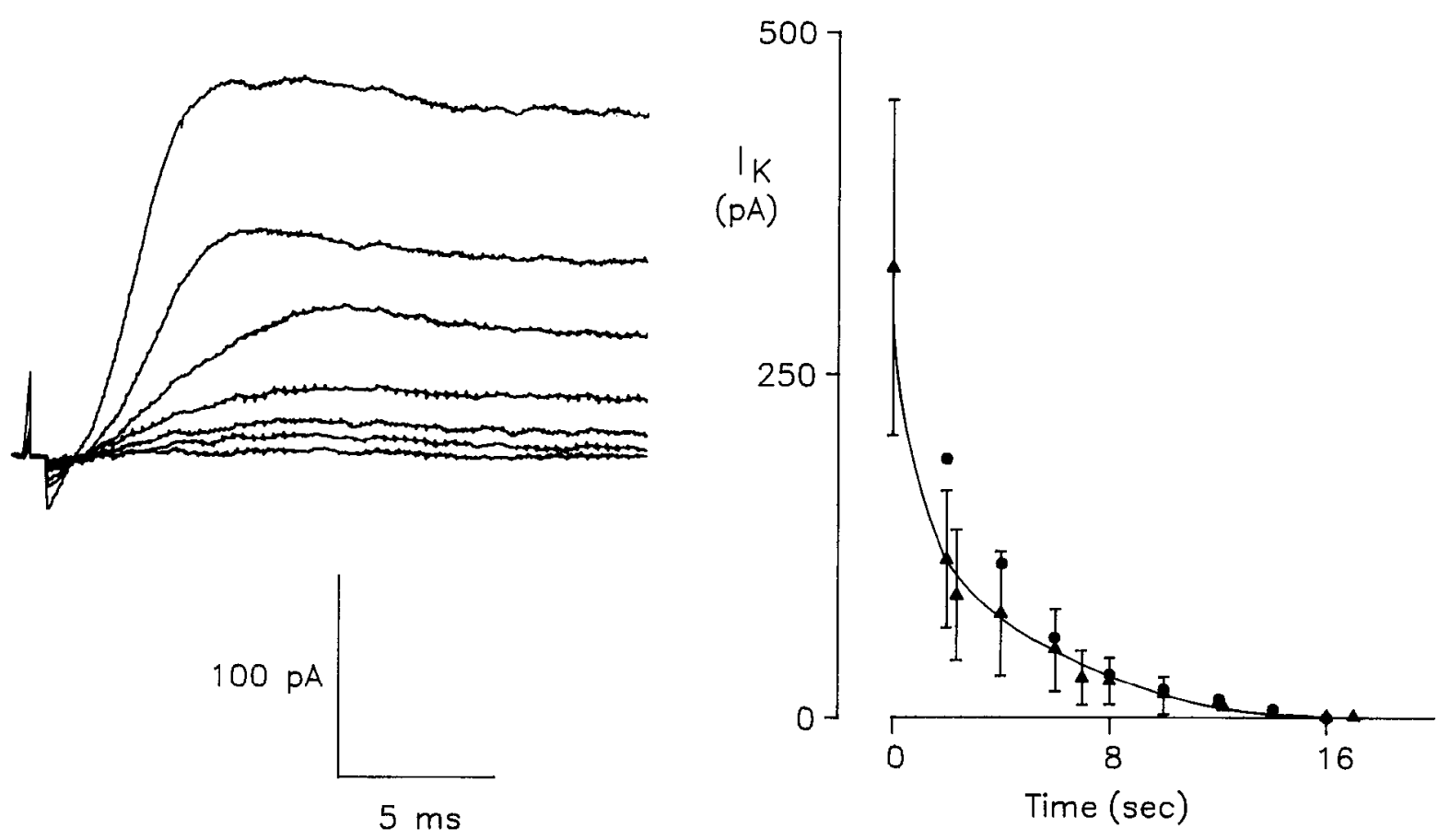

Figure 4. Disappearance of $\mathrm{K}$ current as intracellular $\mathrm{K}^{+}$was replaced by Cs ${ }^{+}$. Left, Current records were taken at 2 sec intervals from break of patch. Pulse potential was $+17 \mathrm{mV}$; holding potential, $-73 \mathrm{mV}$. Pipet solution was CsAsp; external solution is Tris Dros. saline. Steady-state current record has been subtracted from each record (cell 7/03/7-5). Right, Mean and SD of K currents are plotted (A) versus the time of dialysis with the CsAsp pipet solution. The data for times of $2 \mathrm{sec}$ and greater come from 14 cells. The individual $\mathrm{K}$ currents of the records shown at left are also plotted (0). The mean and SD plotted at $0 \mathrm{sec}$ is from 14 different cells whole-cell clamped with KAsp-filled pipets.

the magnitudes of the inactivating components of $K$ currents are increased by more negative holding potentials. The rapidly inactivating component of $\mathrm{K}$ current is half-inactivated at -70 $\mathrm{mV}$. All neurons studied have a noninactivating component to the K current. When studied with long depolarizing pulses, cells with a slowly inactivating component of $\mathrm{K}$ current are seen to also have a noninactivating component of $K$ current. Since the amplitude of the noninactivating component of Figure $3 B$ was not determined, total current for Figure $3 B$ was plotted against holding potential in Figure $3 D$. Thus, the holding potential dependence of inactivation may be about the same for the slowly inactivating $K$ current as for the rapidly inactivating $K$ current. We observed a continuous range of inactivation rates for the $K$ currents in the 28 cells studied; Figure $3, A$ and $B$, gives examples at the fast and slow ends of the range. However, because of the poor spatial control of the voltage clamp and other complications, it is not possible to conclude how many distinct types of channels carry the inactivating $\mathrm{K}$ current.

Alterations of both internal and external $\mathrm{K}^{+}$concentrations confirm that these outward currents are carried by $\mathrm{K}^{+}$. When the pipet contains a $\mathrm{K}$-free internal solution (CsAsp), there is a rapid disappearance of the depolarization-evoked outward current that can be elicited immediately after breaking the patch on entering the whole-cell configuration. Figure 4 shows the depolarization-evoked outward currents at $2 \mathrm{sec}$ intervals following the break of the patch; the net-inward current that remains in the steady state (after the exchange of ions between the cell and the pipet) has been subtracted from each current record. The plot of Figure 4 gives the average magnitude of the depolarization-evoked outward current (measured from 14 cells studied with CsAsp-filled pipets); the point at zero time was obtained from 14 different cells studied with KAsp-filled pipets.
Assuming that the magnitude of the $\mathrm{K}$ current is roughly proportional to the internal $\mathrm{K}^{+}$concentration, these measurements suggest that the internal $\mathrm{K}^{+}$concentration drops to less than half of its normal value in the first $2 \mathrm{sec}$, but that $\mathrm{K}^{+}$is not depleted from some parts of the cell (probably processes) until $20 \mathrm{sec}$ following membrane break.

The reversal potential of the $\mathrm{K}$ currents is sensitive to external $\mathrm{K}^{+}$, as would be expected for a $\mathrm{K}^{\prime}$ electrode. The reversal potential is determined for the $\mathrm{K}$ current by measuring tail currents (Fig. 5). When the external solution contains $6 \mathrm{~mm} \mathrm{~K}^{+}$, the reversal potential is $-77 \pm 6 \mathrm{mV}(n=5)$, which is close to the $-82 \mathrm{mV}$ calculated from the Nernst equation and the known concentrations of $\mathrm{K}^{+}$. The reversal potential measured for the $\mathrm{K}$ current when the external solution contains $60 \mathrm{mM} \mathrm{K}^{+}$is -15 $\pm 3 \mathrm{mV}(n=5)$, which is close to the $\mathrm{K}^{+}$reversal potential of $-24 \mathrm{mV}$ calculated from the Nernst equation. The experiment of Figure $2 C$ shows directly that these currents reverse direction near $-20 \mathrm{mV}$ when the external solution contains $6 \mathrm{mM} \mathrm{K}^{+}$and internal $\mathrm{K}^{+}$is reduced to $15.6 \mathrm{~mm}$.

The above studies of the Drosophila neuronal K current have probably missed a component of the total $\mathrm{K}$ current that exists in these membranes. Drosophila muscle membrane has $2 \mathrm{Ca}$ dependent K currents (Wei and Salkoff, 1986). Since our studies are done with an EGTA-containing internal solution and a $\mathrm{Ca}$ free external solution (to eliminate $\mathrm{Ca}$ currents), such $\mathrm{Ca}$-dependent $\mathrm{K}$ currents were not measured. When the $\mathrm{K}$ current is measured before and after substituting $\mathrm{Mg}^{2+}$ for external $\mathrm{Ca}^{2+}$ (Fig. 6A), the $\mathrm{K}$ current is found to be $25 \pm 10 \%$ smaller when external $\mathrm{Ca}^{2+}$ is absent. This supports the presence of a $\mathrm{Ca}$ dependent $\mathrm{K}$ current in the neuronal membrane, because contamination by inward Ca current or surface potential shifts of $\mathrm{K}$ current activation would both predict that the outward $\mathrm{K}$ 

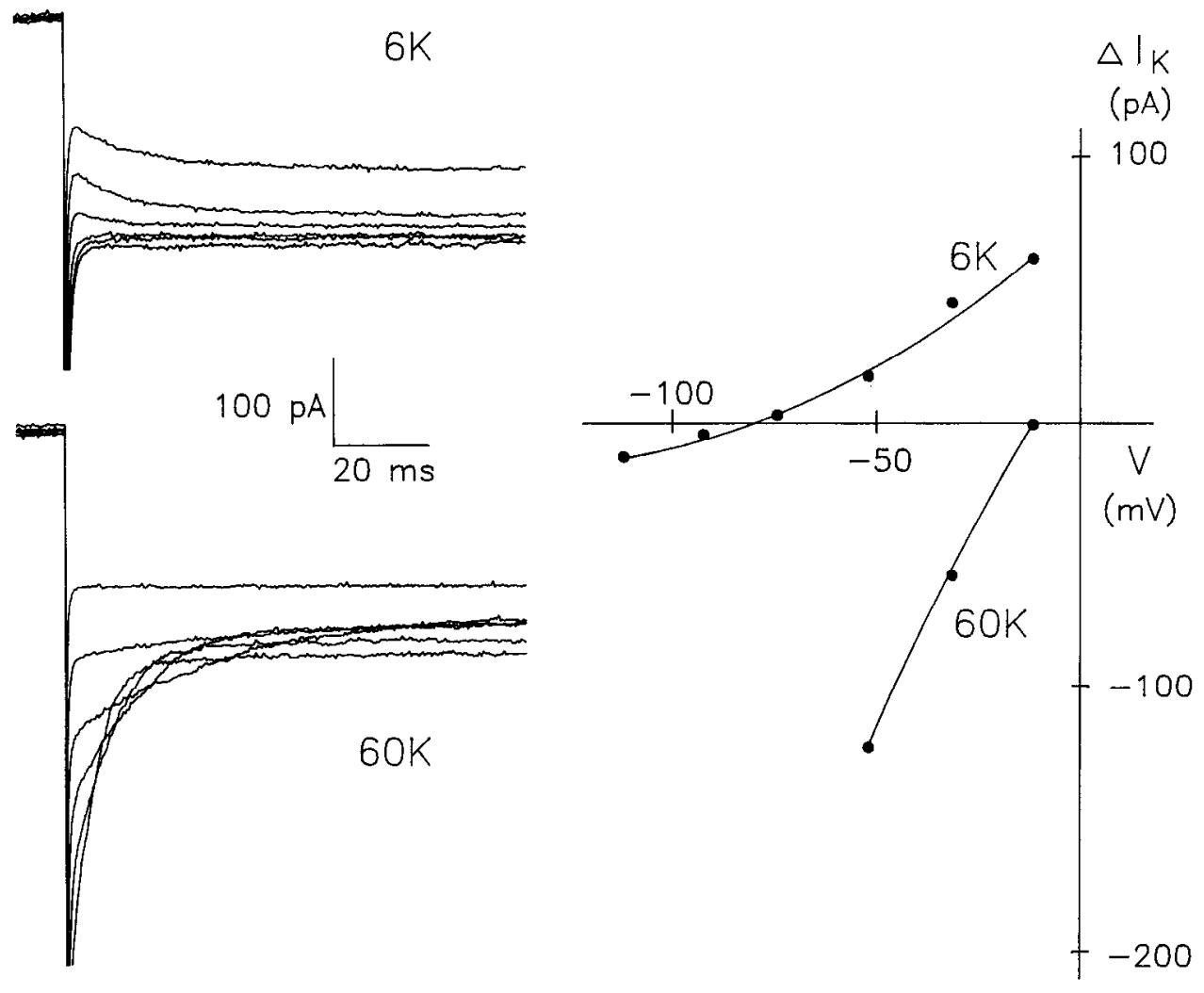

Figure 5. K current reversal potentials. Left, Tail currents are shown for 2 experiments on the same cell in which, after activating the $\mathrm{K}$ current by a 10 msec pulse to $+27 \mathrm{mV}$, the potential was stepped to values from -13 to -113 $\mathrm{mV}$ ( $20 \mathrm{mV}$ decrements). The tail currents are mostly outward when the external solution is $6 \mathrm{~K} / 0 \mathrm{Ca}$ Tris Dros. saline $(6 K)$ and mostly inward when the external solution is $60 \mathrm{~K} / 0 \mathrm{Ca}$ Tris Dros. saline $(60 K)$. The internal solution is KAsp plus 2 mм ATP. Right, Difference between the currents 10 and 100 $\mathrm{msec}$ after the repolarizing step (cell $7 / 15 / 7-13)$. current would appear smaller in the $\mathrm{Ca}^{2+}$-containing solution. The Ca-dependent $\mathrm{K}$ current appears to be a noninactivating $\mathrm{K}$ current (Fig. 6A). In order to avoid contamination by Ca currents, we chose to study the $\mathrm{K}$ currents in a Ca-free external solution.
The $\mathrm{K}$ currents were further characterized by measuring their sensitivity to 2 classical K current blockers, TEA and 4-AP. The addition of $10 \mathrm{mM}$ TEA to the external solution had little blocking effect on the rapidly inactivating $\mathrm{K}$ current ( $n=2$, not shown) but did reduce the noninactivating $\mathrm{K}$ current by $20-30 \%(n=$

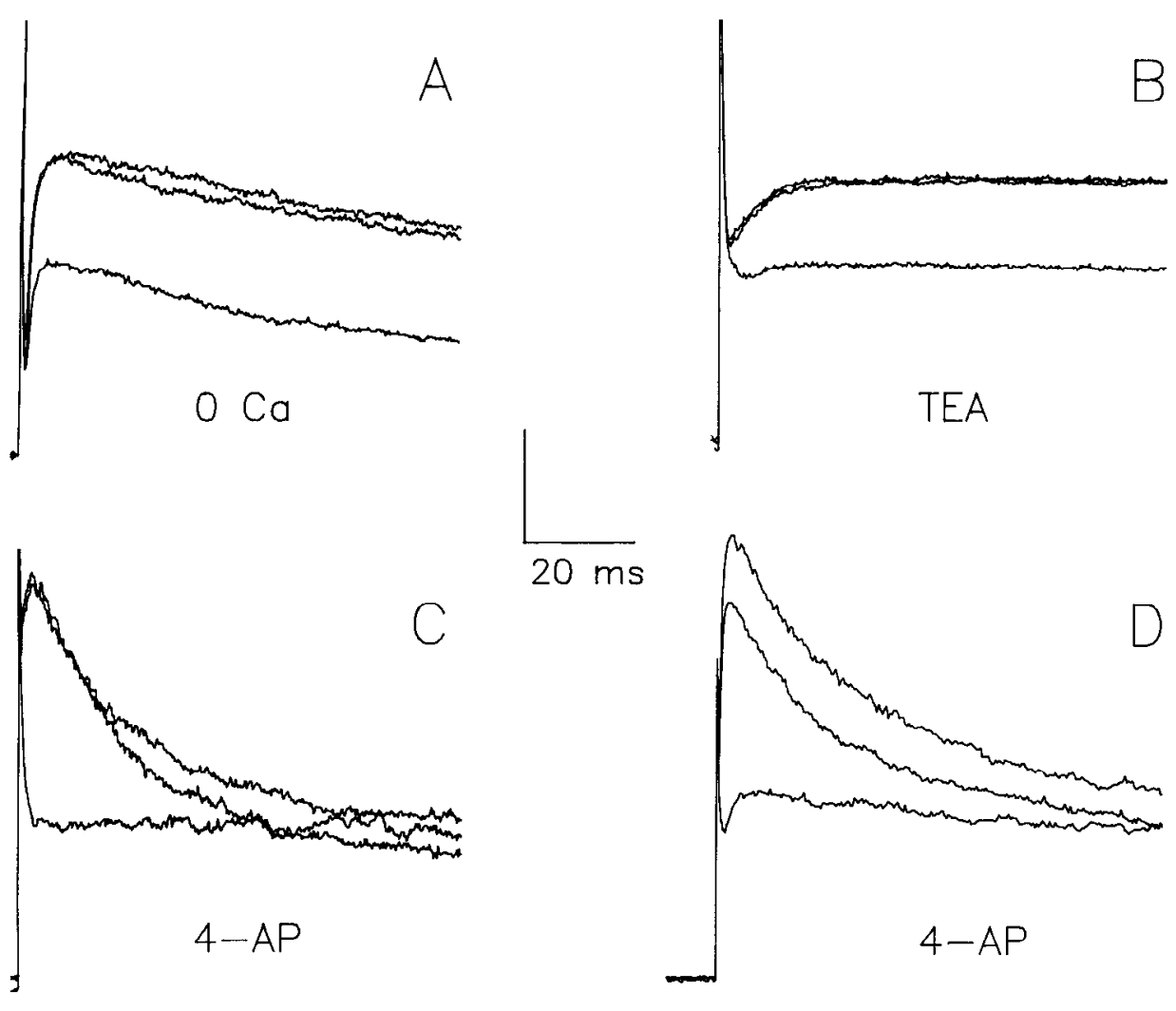

Figure 6. Pharmacological sensitivities of $K$ currents. The $K$ currents elicited by stepping to $+17 \mathrm{mV}$ are shown for control external solution, test external solution and for control solution again after the test solution. The holding potential was $-73 \mathrm{mV}(A-C)$ or $-113 \mathrm{mV}(D)$. The smallest outward current is recorded in the test solution for all 4 cases $(A-D)$. The control solution is $6 \mathrm{~K} / 5 \mathrm{Ca}$ Tris Dros. saline $(A)$ or $6 \mathrm{~K} / 0 \mathrm{Ca}$ Tris Dros. saline $(B-D)$. The test solution is $6 \mathrm{~K} / 0 \mathrm{Ca}$ Tris Dros. saline $(A)$, or $6 \mathrm{~K} / 0 \mathrm{Ca}$ Tris Dros. saline plus $10 \mathrm{~mm}$ TEA $(B)$ or $6 \mathrm{~K} / 0 \mathrm{Ca}$ Tris Dros. saline plus $10 \mathrm{~mm} 4-\mathrm{AP}(C$ and $D$ ). The internal solution is KAsp with $2 \mathrm{~mm}$ ATP. The current scale is $200 \mathrm{pA}$ $(A, B$, and $D)$ or $100 \mathrm{pA}(C)$. Cells $7 / 10 /$ 7-24 $(A), 7 / 15 / 7-17(B), 7 / 15 / 7-93(C)$, and $7 / 15 / 7-52(D)$. 
Figure 7. Na currents. $A-C, \mathrm{Na}^{+}$dependence of inward currents. Potential was stepped to $-45,-25,-5$, and +15 $\mathrm{mV}$ from a holding potential of -65 nal solution was Dros. saline $(A)$, Tris Dros. saline $(B)$, or $0 \mathrm{~K}$ Dros. saline $(C)$ (cell 4/29/6-10). D, Small Na currents. Potential was stepped to values from -41 to $+9 \mathrm{mV}$ (10 $\mathrm{mV}$ increments); holding potential was $-71 \mathrm{mV}$. Internal solution was CsAsp; external solution, Dros. saline (cell $1 / 16 / 6-18) . E$, Current-voltage relations for cell $4 / 29 /$ 6-10 (circles) and cell 1/16/6-18 (triangles). Filled symbols for currents in $130 \mathrm{~mm} \mathrm{Na}$; open symbols, currents in $\mathrm{Na}$-free solution. $\mathrm{mV}$. Internal solution was CsF. Exter-
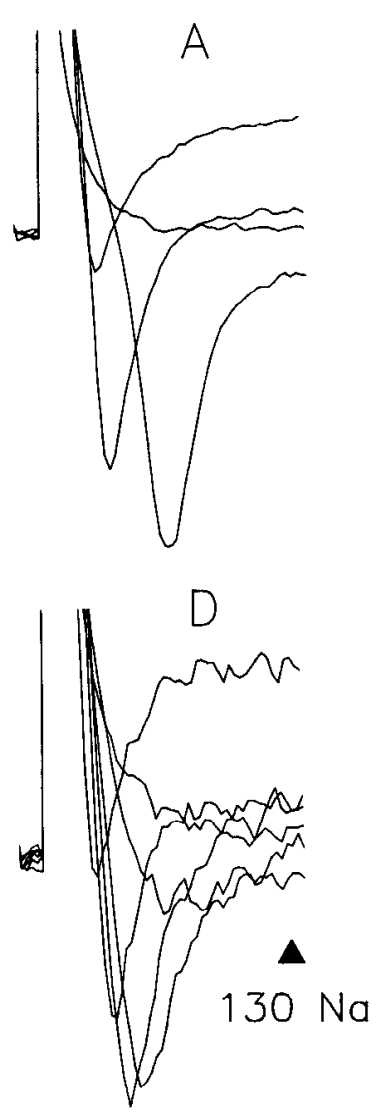

4; Fig. 6B). In contrast, $10 \mathrm{~mm}$ 4-AP almost completely blocked $(80-100 \% ; n=4)$ the inactivating $\mathrm{K}$ current but had little effect $(<15 \% ; n=5)$ on the noninactivating $\mathrm{K}$ current (Fig. 6, $C$ and $D$ ). These different sensitivities to block by 4-AP support the interpretation that the inactivating and noninactivating $\mathrm{K}$ currents are carried by distinct channels.

\section{Sodium current}

When the extracellular solution is Dros. saline (140 mM Na) and the intracellular solution is $\mathrm{K}$-free, depolarizing voltage steps are seen to elicit rapidly inactivating inward currents (Fig. $7, A, D)$. These currents are Na currents because removing external $\mathrm{Na}^{+}$reversibly eliminates them (Fig. $7 A-C$ ) and $100 \mathrm{~nm}$ TTX completely blocks them. (Lower concentrations of TTX have not been tried.) The peak magnitude of the $\mathrm{Na}$ currents in these cells varies from 0 to $100 \mathrm{pA}$. Neurons with Na currents greater than $70 \mathrm{pA}$ are commonly found. The larger $\mathrm{Na}$ currents clearly escape from voltage control, the maximum $\mathrm{Na}$ current appearing abruptly as the depolarizing voltage steps are gradually made more positive. However, when the $\mathrm{Na}$ current is smaller (Fig. 7, $C, D$ ), the voltage control is better, and the resulting current-voltage curves (Fig. $7 E$ ) probably give a fairly accurate representation of the voltagc dependence of activation of the $\mathrm{Na}$ channels. $\mathrm{Na}$ currents activate above $-40 \mathrm{mV}$ and reach a maximum near $-10 \mathrm{mV}$.

\section{Calcium current}

When the pipet contains $\mathrm{CsCl}$ or $\mathrm{CsAsp}$ solutions and the external solution has no $\mathrm{Na}^{+}$or $\mathrm{K}^{+}$(Tris Dros. saline), it can be seen that depolarizing voltage steps elicit $\mathrm{Ca}$ currents. In general, the voltage control of the Ca currents is not good, but Figure 8

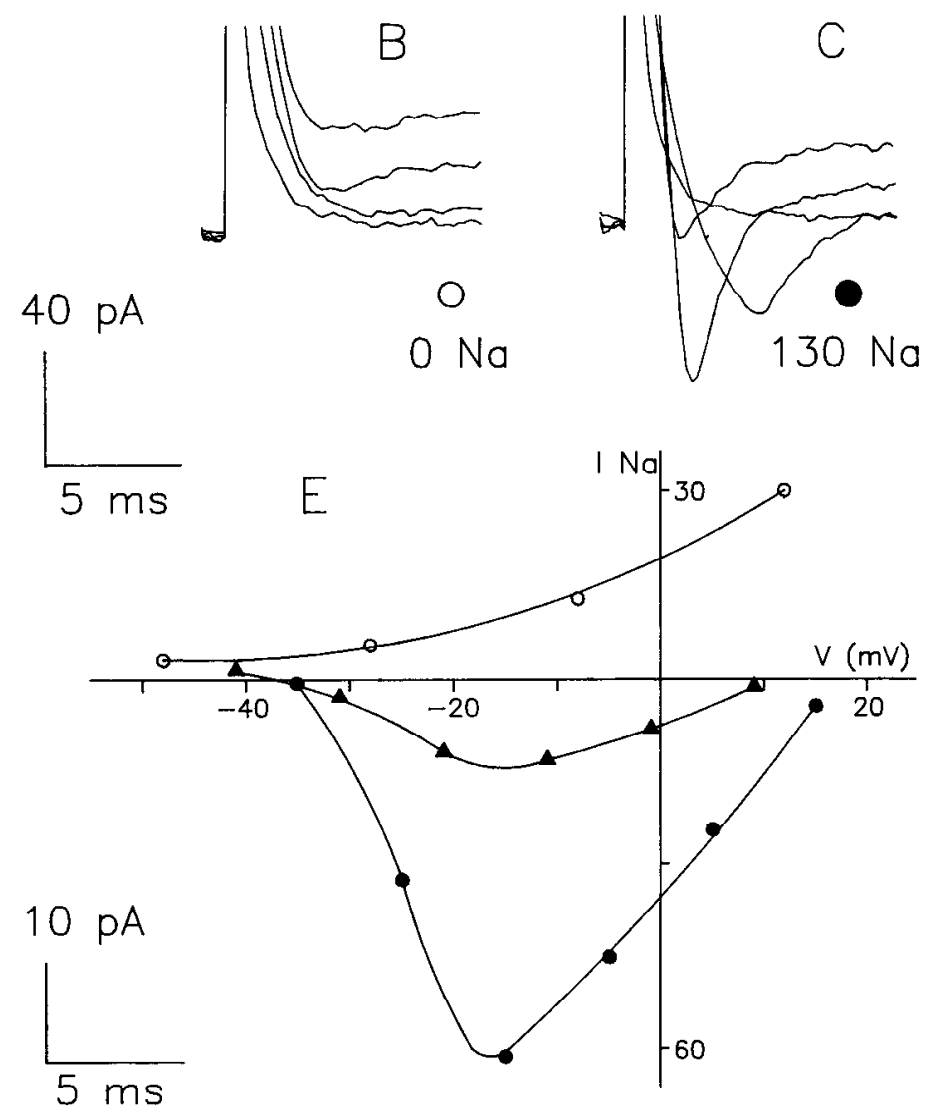

shows current recordings and current-voltage relations for 2 cells in which voltage control seemed fairly good, as judged by the gradual increase of $\mathrm{Ca}$ current with potential (negative slope region). The $\mathrm{Ca}$ current activates at potentials above $-40 \mathrm{mV}$ and reaches a maximum near $0 \mathrm{mV}$. In some cells the Ca current shows almost no inactivation (lower records, Fig. 8), while the Ca current appears to decay considerably in others (upper records, Fig. 8). It is not known if this corresponds to different types of Ca channels, different extents of control of intracellular $\mathrm{Ca}^{2+}$ concentration, or different amounts of contamination by a slowly activating outward current. The exchange of ions between the pipet and the cytoplasm of the processes is limited so that outward $\mathrm{K}$ currents may not be completely eliminated. In early experiments we found that replacing external $\mathrm{K}^{+}$with Tris $^{+}$reduces the outward currents evoked by large depolarizations when the pipet solution contains no $\mathrm{K}^{+}$. We think these outward currents are $\mathrm{K}$ currents that result from an accumulation of $\mathrm{K}^{+}$within the processes when $\mathrm{K}^{+}$enters the membrane of the processes faster than it can diffuse to the pipet. To minimize contamination by $\mathrm{K}$ currents, the Ca currents are always studied in $\mathrm{K}^{+}$-free external solutions.

These inward currents evoked by depolarization in $\mathrm{Na}^{+}$-free solution are $\mathrm{Ca}$ currents since they are reversibly eliminated by replacing external $\mathrm{Ca}^{2+}$ with $\mathrm{Mg}^{2+}$ (Fig. 9, upper) and are almost completely blocked by 0.1 mм Cd ${ }^{2+}$ (Fig. 9, lower). The background currents that remain after eliminating the $\mathrm{Ca}$ current by either of these procedures are usually small and nearly linear. This suggests that these $\mathrm{Ca}$ currents are only contaminated by a small leakage. Another result that identifies these $\mathrm{Ca}$ currents is that $\mathrm{Ba}^{2+}$ can also carry the inward current. When external $\mathrm{Ca}^{2+}$ is replaced by $\mathrm{Ba}^{2+}$, the inward current becomes larger and 

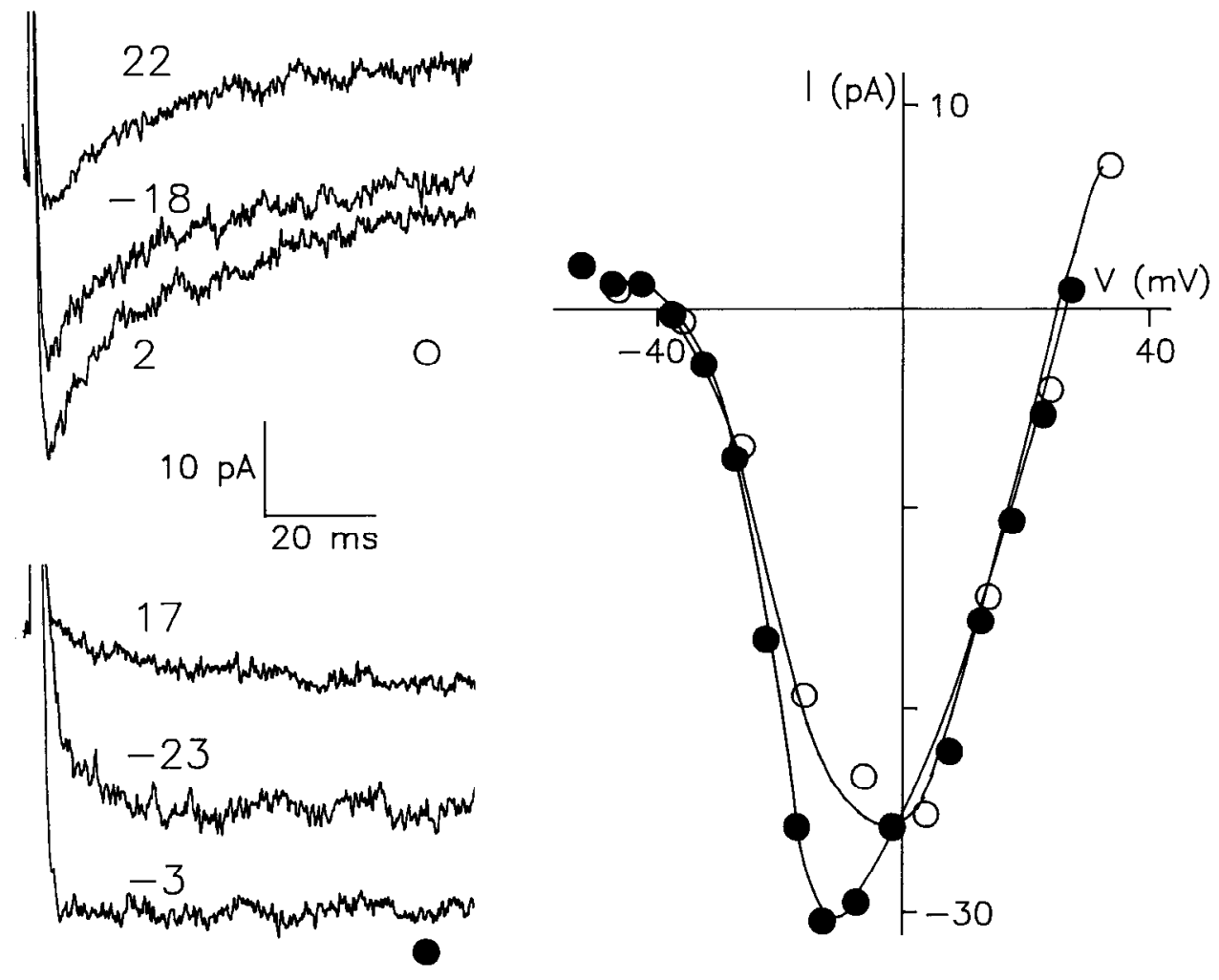

Figure 8. Voltage-dependent activation of $\mathrm{Ca}$ currents. The current records are taken from 2 cells in Tris Dros. saline when the membrane potential was stepped from the holding value to the values indicated on the current records (in $\mathrm{mV}$ ). Upper left, Internal solution was CsCl plus 2 mM ATP, and the holding potential was $-68 \mathrm{mV}$ (cell 1/14/ 6-14). Lower left. Internal solution was CsAsp enriched with ATP, dibutyryl cAMP, and theophylline, and the holding potential was $-73 \mathrm{mV}$ (cell 12/29/ 6-13). Right, Current-voltage relations for peak inward current of cell $1 / 14 / 6$ $14(0)$ and cell 12/29/6-13 (O).
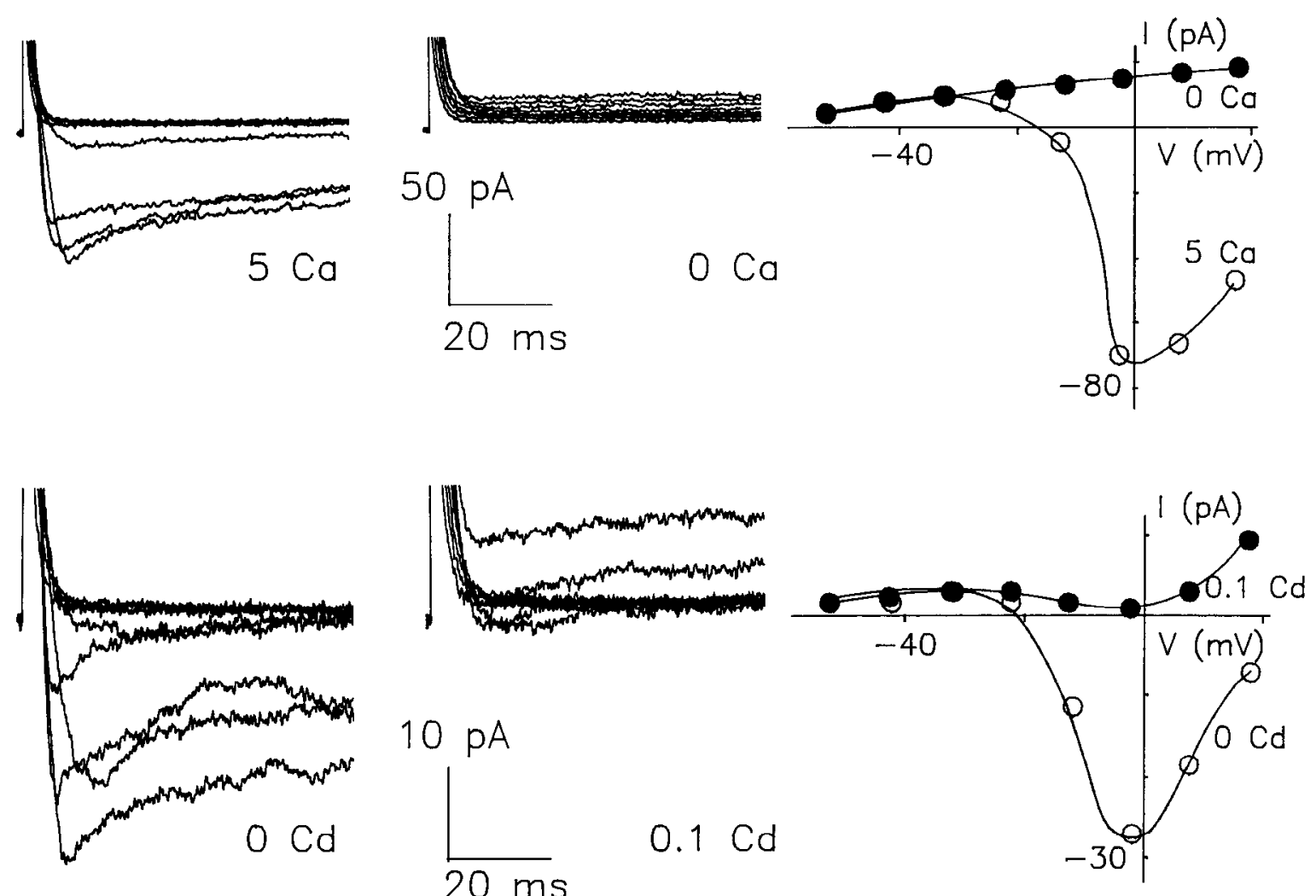

Figure 9. Identification of Ca current. Currents were recorded during steps from $-73 \mathrm{mV}$ to levels between -53 and $+17 \mathrm{mV}$ (10 $\mathrm{mV}$ increments). Left, Control Ca currents from 2 cells. Internal solution was enriched CsAsp; external solution, Tris Dros. saline. Center, Current records obtained when the external solution was changed to 0 Ca Tris Dros. saline (upper, cell 6/17/7-10) or Tris Dros. saline plus $0.1 \mathrm{~mm} \mathrm{Cd}^{2+}($ lower, cell $10 / 2 /$ 6-7). Right, Control $(O)$ and test $(0)$ currents plotted against voltage. 
Figure 10. Ba currents in cell $4 / 25 / 7$ 27. Currents are recorded during steps of potential from a holding level of -73 $\mathrm{mV}$ to values from -53 to $+17 \mathrm{mV}(10$ $\mathrm{mV}$ increments). The internal solution was enriched CsAsp. The cell was first studied in Tris Dros. saline $(A, O)$, then in Ba Tris Dros. saline $(B, \triangle)$, and finally in Tris Dros. saline again $(C, \bullet)$. Peak inward currents are plotted against
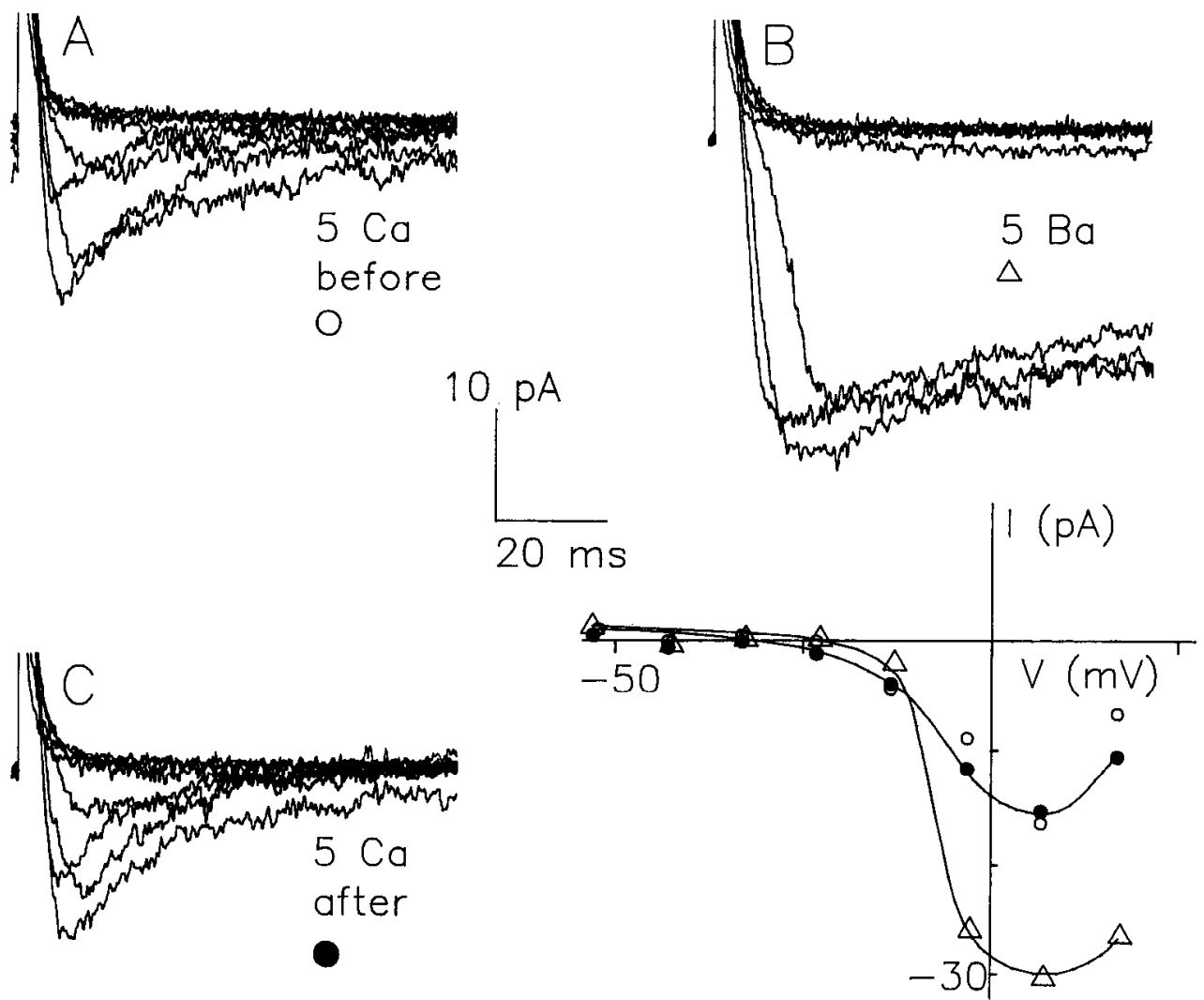
potential.

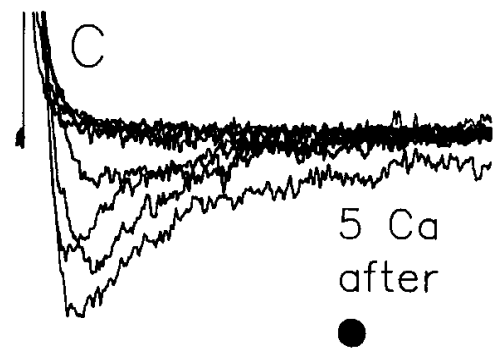

the apparent inactivation decreases (Fig. 10). Since the magnitude of the Ca current generally declined with time (washout), we compared the magnitude of the $\mathrm{Ca}$ (or $\mathrm{Ba}$ ) current to the mean of the $\mathrm{Ba}$ (or $\mathrm{Ca}$ ) currents measured just before and after. From 10 measurements the ratio of peak Ba current to peak $\mathrm{Ca}$ current was $2.3 \pm 0.4$ (mean $\pm \mathrm{SD}$ ). The magnitude of the $\mathrm{Ba}$ current increased by $2.8 \pm 0.9(n=5)$ when the external concentration of $\mathrm{Ba}^{2+}$ was increased from 5 to $107 \mathrm{~mm}$ (the concentration of $\mathrm{Ba}^{2+}$ used in the pipet when searching for single Ca channel currents, see below).

The magnitude of the Ca current varied greatly from neuron to neuron, being negligibly small in some cells but greater than $100 \mathrm{pA}$ in others. Figure 11 shows the distribution of peak $\mathrm{Ca}$ current magnitudes measured for 266 cells under standard conditions. The mean current was $41 \mathrm{pA}$ and the SD was $33 \mathrm{pA}$. All magnitudes were measured within $1 \mathrm{~min}$ after starting wholecell recording, before appreciable $\mathrm{Ca}$ current washout had occurred. Since the diameters of the cells studied varied by less than a factor of 2 and the total capacitance calculated from the capacitive transient (see above) varied by less than 8 , the measured distribution of $\mathrm{Ca}$ current magnitudes clearly indicates a large variation between cells in the density of Ca channels. We have not been able to identify any characteristic of the neurons that correlates with the magnitude of the $\mathrm{Ca}$ current, except for a dependence on culture age. Neurons studied 24-32 hr after egg laying had mean Ca currents of $24 \mathrm{pA}$, while neurons studied between 48 and $56 \mathrm{hr}$ had mean Ca currents of $41 \mathrm{pA}$. The mean increased to $46 \mathrm{pA}$ for all neurons studied after $72 \mathrm{hr}$.

Not only did inactivation vary from cell to cell as judged by the apparent decay of the Ca current during a maintained depolarization, but there was also considerable variation of the steady-state inactivation measured with 1 -sec-long prepulses
(Fig. 12). For some cells the Ca current evoked by stepping to $-3 \mathrm{mV}$ was the same for any prepulse more negative than -50 $\mathrm{mV}$, while for other cells even prepulses of $-80 \mathrm{mV}$ inactivated some of the Ca current (Fig. 12). As can be seen, the amount of current decay during the depolarizing pulse did not correlate with the sensitivity to prepulses. It might be suggested that cells demonstrating little sensitivity to prepulses are just poorly clamped so that the $\mathrm{Ca}$ channels do not see the prepulse potentials. However, a study of the voltage dependence of activation of these cells did not support the idea that the quality of the voltage clamp was poorer for those cells that had little sensitivity to prepulses.

The Ca current of these Drosophila neurons "washes out" fairly rapidly with the CsAsp internal solution in the pipet. However, the magnitude of Ca current in some cells shows very little washout when the internal CsAsp is supplemented with agents that might support phosphorylation ( 2 mM ATP, $100 \mu \mathrm{M}$ dibutyryl cAMP, and 2 mM theophylline). With the simple CsAsp internal solution, the magnitude of the Ca current fell to $51 \%$ of its initial value on average $(n=8)$ in $5 \mathrm{~min}$, the range was $42-65 \%$ (Fig. 13). The effect of including ATP, dibutyryl cAMP, and theophylline in the internal solution was studied on 12 neurons on the same days as the measurements were made on cclls without ATP. With the enriched solution, the Ca current fell on average to $72 \%$ of the initial value in $5 \mathrm{~min}$, the range being $51-100 \%$ (Fig. 13). Thus, the addition of these phosphorylation-promoting agents eliminated washout in some cells but had little effect on the washout in other cells. We do not know if this high variability in washout rate with ATP, etc., in the pipet is due to differences in the types of $\mathrm{Ca}$ channels involved or differences in the degree of exchange between the pipet and the cytoplasm in the region of the $\mathrm{Ca}$ channels. The following 

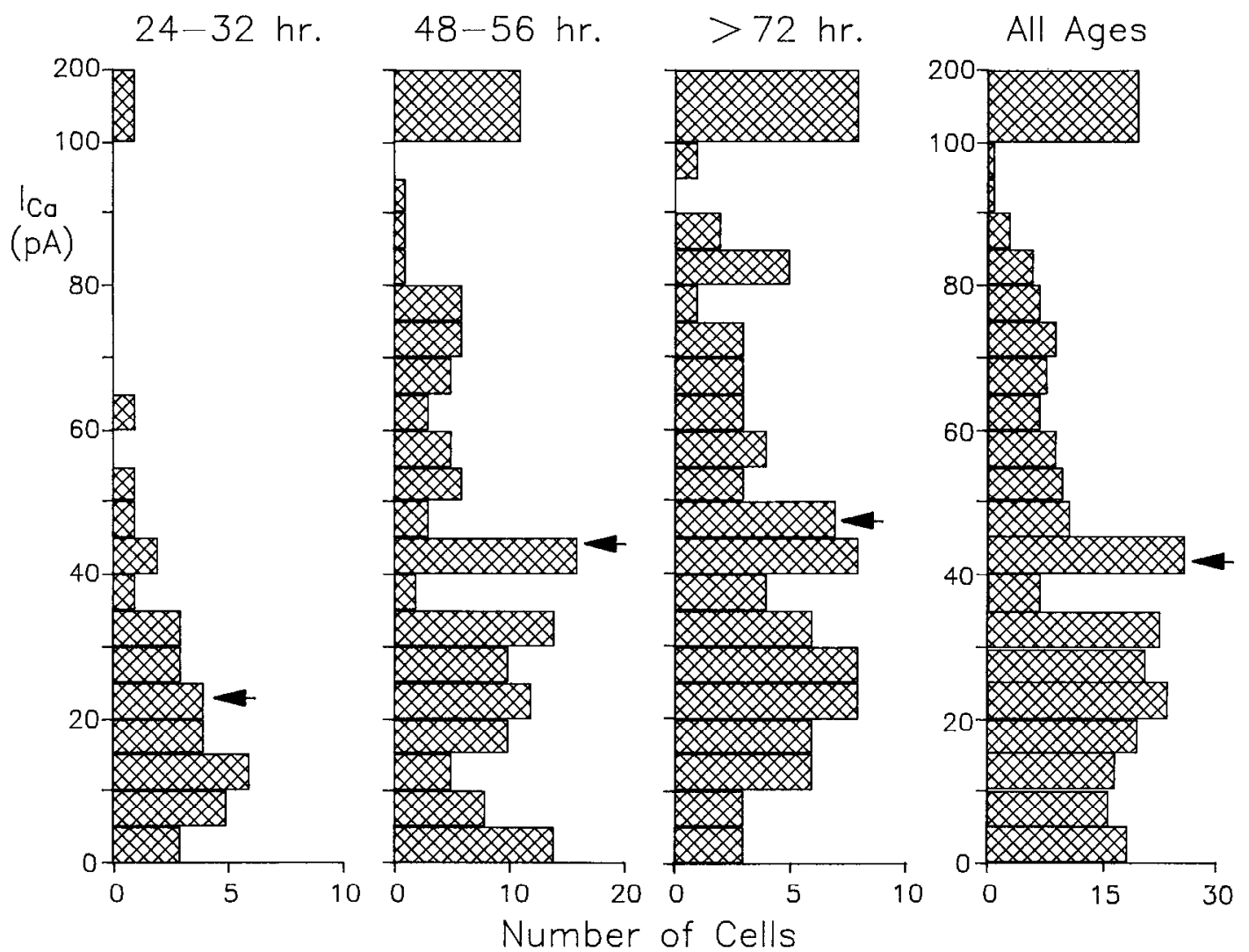

Figure 11. Distribution of Ca current magnitudes. Histograms were made of the peak Ca current recorded at the beginning of whole-cell studies with CsAsp for internal solution and Tris Dros. saline for external solution. Separate histograms are presented for cells of 3 ages and for the combined ages. Ages were measured from time of egg laying. Arrows indicate the mean value of Ca current for each population of cells.

studies of the effects of pharmacological agents on the Ca current are done with enriched CsAsp solution in the pipet, since stable $\mathrm{Ca}$ currents are necessary to measure weak blocking effects.

Three types of organic $\mathrm{Ca}$ antagonists have been found to block the Ca currents of vertebrate cardiac and smooth muscle at low concentrations: dihydropyridines, phenylalkylamines, and benzodiazepines (Janis et al., 1985). None of these are very effective at blocking the Ca current of Drosophila neurons; however, the phenylalkylamines do have a weak blocking effect. The dihydropyridine nifedipine had no effect on the Ca current, even at a near-saturation concentration $(10 \mu \mathrm{M})$. One of the 4 tests of nifedipine is shown in the top record of Figure 14. Although a 5 min exposure to nifedipine had no discernible effect on the current, $100 \mu \mathrm{M} \mathrm{Cd}^{2+}$ completely blocked the inward current in less than a minute, confirming that this inward current was a $\mathrm{Ca}$ current and that the external perfusion was effective. The dihydropyridine BAY K 8644, which acts as a Ca channel agonist on many cells (Hess et al., 1984), also had no effect on the Ca currents of the 2 Drosophila neurons on which it was tested (at $10 \mu \mathrm{M}$ ). As shown in the bottom record of Figure 14, the benzodiazepine dilitiazem $(100 \mu \mathrm{M})$ had no effect on the $\mathrm{Ca}$ current, although the Ca current was completely and reversibly eliminated by either removing external $\mathrm{Ca}^{2+}$ or adding $100 \mu \mathrm{M}$ $\mathrm{Cd}^{2+}$; this result was duplicated in 2 additional trials. The phenylalkylamines verapamil and D-600 did weakly block the Drosophila $\mathrm{Ca}$ current at a high concentration $(100 \mu \mathrm{M})$. Verapamil blocked the Ca current by $25 \pm 9 \%(n=5)$; one example is shown in top record of Figure 15. D-600 blocked the Ca current by $28 \pm 6 \%(n=7)$. However, at $10 \mu \mathrm{M}$ verapamil did not noticeably block the Ca current $(n=4)$. Since the block by organic $\mathrm{Ca}$ channel antagonists has been shown to be voltage dependent (Bean, 1984; Ganitkevich et al., 1986), we tested the above $\mathrm{Ca}$ blockers while holding the cells at depolarized levels (around $-50 \mathrm{mV}$ ). This did not noticeably increase the blocking effectiveness of the drugs, but it did increase the irreversible loss of the Ca current. We also tested for use dependence of the D-600 block since use dependence has been shown for the D-600 block of $\mathrm{Ca}$ currents in vertebrate cardiac and smooth muscle (Lee and Tsien, 1983; Ganitkevich et al., 1986). Comparing the $\mathrm{Ca}$ current elicited by repetitive pulses from holding potentials of -50 and $-80 \mathrm{mV}$, with and without D-600, it was not possible to distinguish a use dependence of the block from the background inactivation and washout.

The calmodulin inhibitor W-7 has been found to be an effective inhibitor of the voltage-dependent $\mathrm{Ca}$ current of Paramecium (Ehrlich et al., 1987). As shown in Figure 15 (lower), $100 \mu \mathrm{M}$ W-7 completely blocks the Ca current of Drosophila neurons. However, the action of W-7 is not specific for the Ca current; at $100 \mu \mathrm{M} \mathrm{W}-7$ also completely blocks the K current and causcs the cell to become leaky and fall apart within $5 \mathrm{~min}$ of its application. The capacitive transients are unaffected by $\mathrm{W}-7$, so it does not seem to change the amount of membrane being voltage clamped. At $10 \mu \mathrm{M} \mathrm{W}-7$ does not completely block the Ca current, but the cell still becomes leaky within a few minutes.

An effort was made to record the current of single Ca channels. To avoid the problem of $\mathrm{Ca}$ channel washout in isolated patches (Fenwick et al., 1982; Nilius et al., 1985), the currents from cell- 
Figure 12. Steady-state inactivation. $\mathrm{Ca}$ currents are evoked by stepping the potential to $-3 \mathrm{mV}$ following a $1 \mathrm{sec}$ pulse at potentials from -93 to -43 $\mathrm{mV}$ (10 $\mathrm{mV}$ increments). Current records are shown for 2 cells, one for which the Ca current shows the least sensitivity to the prepulse potential (upper, $\mathrm{O}$; cell 5/28/6-3) and one which shows the most sensitivity to the prepulse potential (lower, $\Delta$; cell 2/19/7-3). The peak $\mathrm{Ca}$ current is plotted against the potential of the prepulse. Filled circles show the mean relation obtained from 15 cells, including the 2 examples shown.

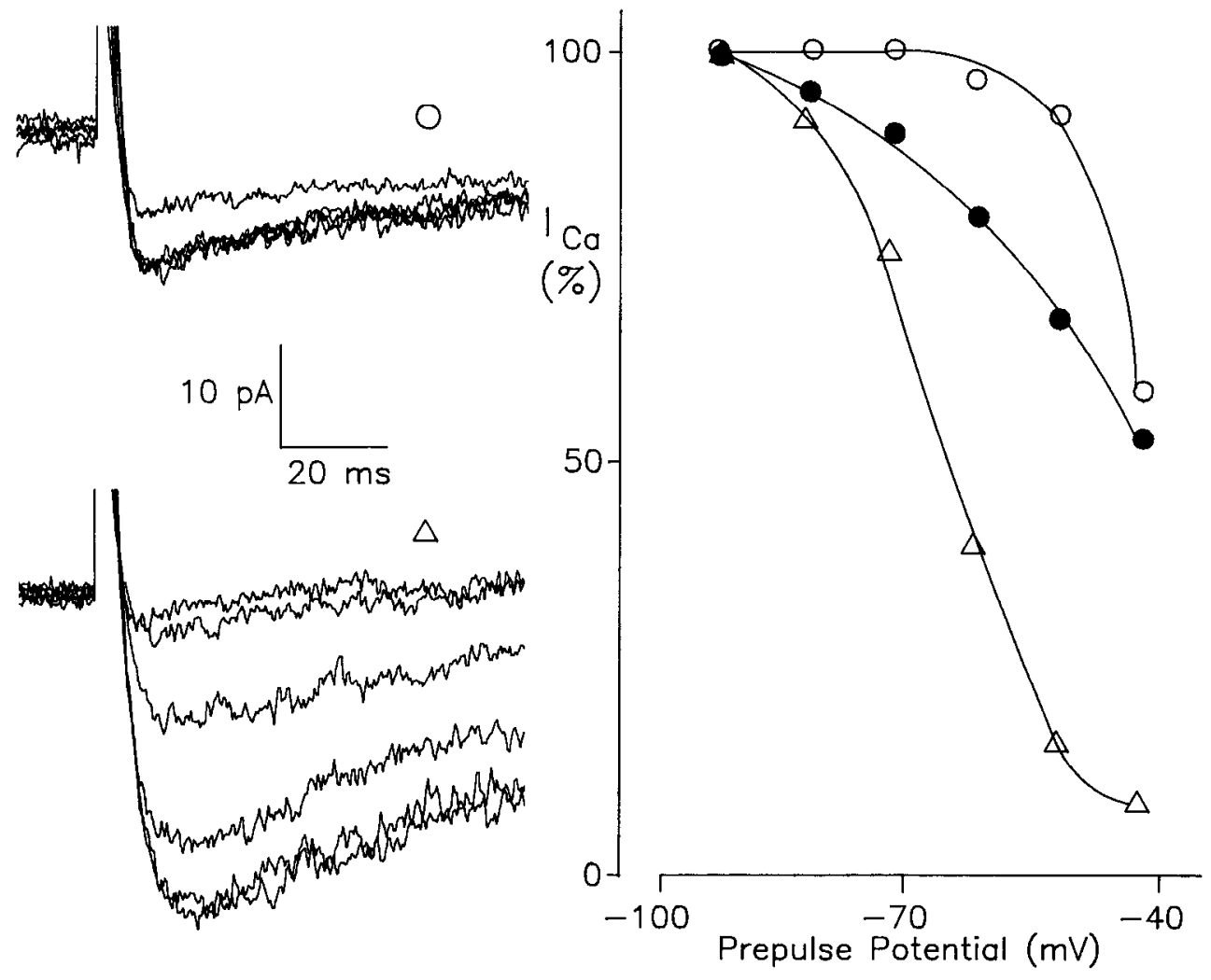

attached patches were studied. When the pipet contained Dros. saline, voltage-dependent single-channel $\mathrm{K}$ currents were frequently seen. However, when the pipet was filled with High Ba saline to give maximum currents through $\mathrm{Ca}$ channels and to block K currents, no inward single-channel currents evoked by depolarization were seen, even though 47 patches with highresistance seals were studied. The amplitude of the background noise was almost always less than $0.2 \mathrm{pA}$ when the patch current was filtered at $2 \mathrm{kHz}$. The mean outward $\mathrm{K}$ current seen with Dros. saline in the pipet at potentials near $+20 \mathrm{mV}$ was less than $1 \mathrm{pA}$ per patch. Considering that the mean whole-cell $\mathrm{K}$ current was more than $300 \mathrm{pA}$ at this potential and assuming a uniform distribution of $\mathrm{K}$ channels, the area of the cell-attached patch would only be one-thousandth (or less) that of the whole cell. Since the mean whole-cell Ba current is about 200 $\mathrm{pA}$ at $0 \mathrm{mV}$ for isotonic $\mathrm{BaCl}_{2}$ outside (see above), a uniform distribution of $\mathrm{Ca}$ channels would give a mean $\mathrm{Ba}$ current of only a few tenths of a picoampere per patch. Thus, if the single $\mathrm{Ca}$ channel current is itself less than $0.2 \mathrm{pA}$ (the noise level), the Ba current would probably not be detected in these patches, even if the $\mathrm{Ca}$ channels were uniformly distributed. So we conclude either that the single $\mathrm{Ca}$ channels currents are quite small $(<0.2 \mathrm{pA})$ or that the Ca channels are preferentially located in the processes or the bottom surface of the soma.

\section{Discussion}

Although the presence of processes on the neurons studied here has prevented precise quantitative characterization of the voltage-dependent $\mathrm{K}, \mathrm{Na}$, and $\mathrm{Ca}$ currents of Drosophila neurons, we are most impressed by the similarity of these currents to those of the molluscan neurons, which have been much better characterized and provide much of our basis for understanding neural electrical activity (Meech, 1986). Even though the cell bodies of the Drosophila neurons are less than one-tenth the size (diameter) of molluscan neurons and Drosophila whole-cell currents are 1000 times smaller than molluscan currents, the only clear difference in the properties of the membrane channels is that Drosophila Na channels are much more sensitive to TTX than are those of molluscan cell bodies (Geduldig and Junge, 1968). The TTX sensitivity of Drosophila Na channels is like that of squid axon and vertebrate nerve (Hille, 1984). We have studied only the $\mathrm{Ca}^{2+}$-independent $\mathrm{K}$ currents, but these currents show multiple components with very different rates of inactivation from cell to cell, as is the case in molluscan nerve cell bodies (Aldrich et al., 1979; Byerly and Moody, 1986). In Drosophila, 4-AP is more effective in blocking the inactivating $\mathrm{K}$ currents than the noninactivating $\mathrm{K}$ currents, as is the case in molluscan neurons (Thompson, 1977). The Ca currents of Drosophila neurons are very similar to those of molluscan neurons and many other invertebrate and vertebrate cells. They appear to have $\mathrm{Ca}^{2+}$-dependent inactivation and are not selectively blocked by the organic $\mathrm{Ca}$ blockers, a property that seems to be common to all invertebrate, as well as some vertebrate, $\mathrm{Ca}$ channels (Hagiwara and Byerly, 1981; Byerly and Hagiwara, 1988).

Voltage-clamp studies of Drosophila Ca currents have also been done on flight muscle (Salkoff and Wyman, 1983a). It is not yet possible to decide if there are fundamental differences between the adult muscle $\mathrm{Ca}$ current and embryonic neuron $\mathrm{Ca}$ current. In muscle, the Ca currents appear to inactivate fairly rapidly and completely, while often the Ca currents show almost no inactivation in embryonic neurons; however, this difference may reflect only the higher buffering of intracellular $\mathrm{Ca}^{2+}$ (by EGTA) in the whole-cell clamped neurons. Salkoff and Wyman found that muscle Ba currents did not inactivate, consistent with the idea of $\mathrm{Ca}^{2+}$-dependent inactivation of the $\mathrm{Ca}$ current 

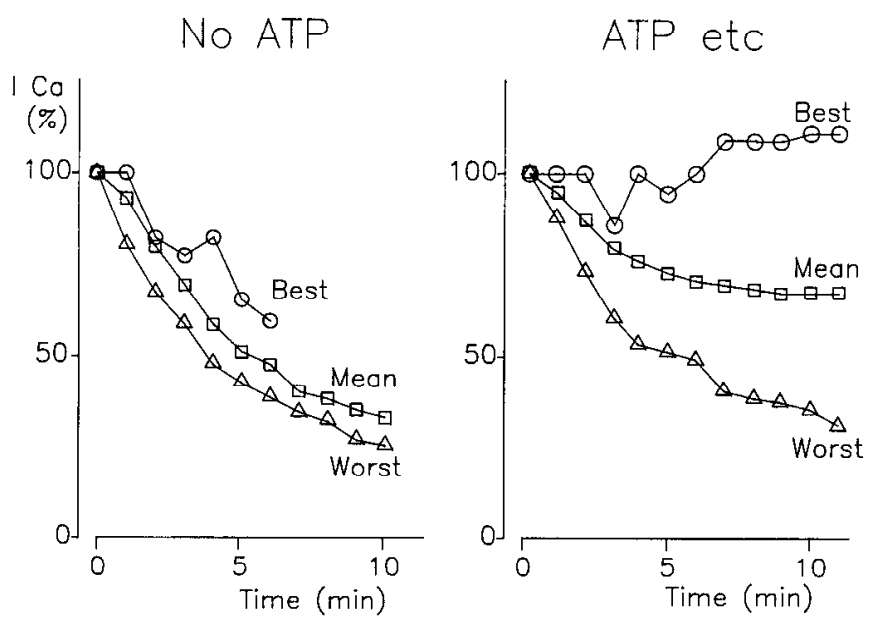

Figure 13. Survival of Ca current. The peak Ca current evoked by depolarization was measured at $1 \mathrm{~min}$ intervals following the beginning of whole-cell recording. Ca currents are first measured $0.5-1.0 \mathrm{~min}$ following the break of the patch to allow for complete depletion of internal $\mathrm{K}^{+}$; all currents are expressed as a percentage of this first measurement. External solution was Tris Dros. saline. Left, Internal solution was CsAsp. Mean for 8 cells. Best cell, 12/12/6-1; worst cell, 12/19/66. Right, Internal solution was CsAsp enriched with $2 \mathrm{mM}$ ATP, $100 \mu \mathrm{M}$ dibutyryl cAMP, and $2 \mathrm{~mm}$ theophylline. Mean for 13 cells. Best cell, 12/29/6-6; worst cell, 12/11/6-16.

(Eckert and Chad, 1984) or contamination by a $\mathrm{Ca}^{2+}$-activated outward current. The Ca currents of both muscle and nerve are first activated at potentials about $-40 \mathrm{mV}$. The steady-state inactivation curve measured for flight muscle agrees well with the extreme example given in Figure 12 (open circles) for embryonic neurons, which shows no steady-state inactivation for potentials below $-50 \mathrm{mV}$. Very little data has been reported about blockers for the muscle Ca current, but given the lack of a highly specific blocker for the neuronal $\mathrm{Ca}$ current, it is doubtful that the blockers tested in this study will be able to distinguish muscle and neuronal Ca channels.

Whole-cell voltage-clamp studies of Drosophila $\mathrm{K}$ currents have been extensively applied to larval, pupal, and adult muscle (Salkoff and Wyman, 1983a, b; Salkoff, 1985; Wu and Haugland, 1985; Timpe and Jan, 1987) and recently to cultured embryonic muscle and larval neurons (Solc et al., 1987; Solc and Aldrich, 1988). Cultured larval neurons (Wu et al., 1983) appear to have less of the noninactivating $\mathrm{K}$ current than do embryonic neurons. Solc and Aldrich (1988) found a subpopulation of larval neurons that expressed primarily A-type (inactivating) $\mathrm{K}$ currents with a double-exponential time course (time constants of $10-30$ and $60-300 \mathrm{msec}$ ). The embryonic neurons we studied always had a substantial component of noninactivating $\mathrm{K}$ current, and the time constants of inactivation varied over a broad range, often being less than $10 \mathrm{msec}$ (Fig. 3). In agreement with the finding of Solc and coworkers (1987) that the Shaker mutation does not affect the A current of larval neurons, we have found in preliminary experiments that neither the rapidly inactivating nor the slowly inactivating $\mathrm{K}$ current of embryonic neurons is affected by the Shaker mutation KS133, which eliminates the A-type current of Drosophila muscle (Salkoff and Wyman, 1981; Ganetzky and Wu, 1983; Solc et al., 1987; Timpe and Jan, 1987). The fast inactivating $\mathrm{K}$ current of embryonic neurons is halr inactivated when held for $1 \mathrm{sec}$ at $-70 \mathrm{mV}$ (Fig. 3). This agrees well with the voltage dependence of steady-state

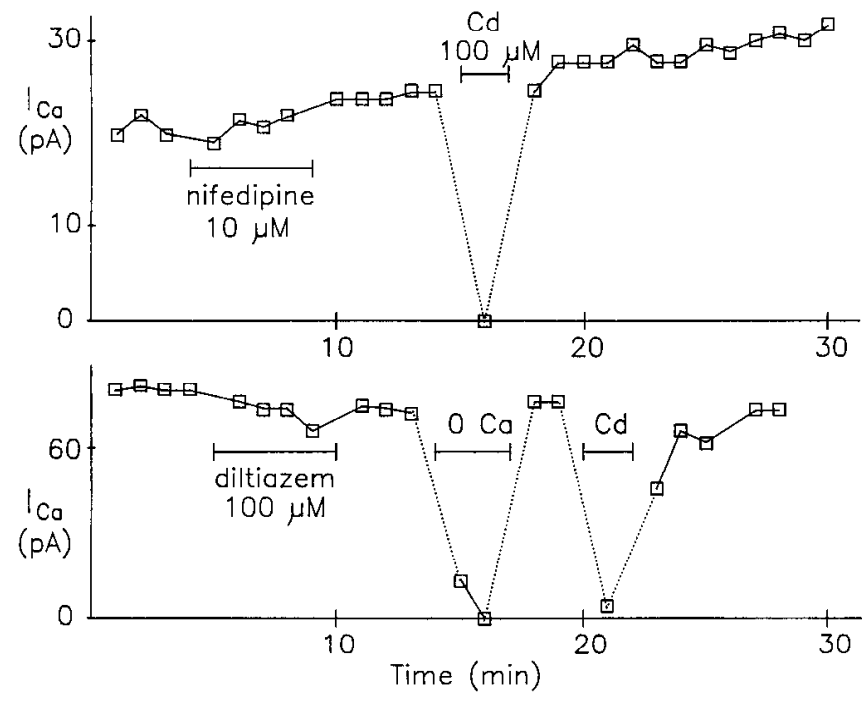

Figure 14. Insensitivity of $\mathrm{Ca}$ current to nifedipine and diltiazem. Peak Ca current was measured at roughly $1 \mathrm{~min}$ intervals while external solution was changed. Internal solution was enriched CsAsp and holding potential was $-73 \mathrm{mV}$. Upper, External solution was Tris Dros. saline. Nifedipine, $10 \mu \mathrm{M}$, or $\mathrm{Cd}^{2+}, 100 \mu \mathrm{M}$, was added during periods indicated (cell 12/29/86-7). Lower, External solution was Tris Dros. saline, except when replaced by $0 \mathrm{Ca}$ Tris Dros. saline $(0 \mathrm{Ca})$. Diltiazem, $100 \mu \mathrm{M}$, or $\mathrm{Cd}^{2+}, 100 \mu \mathrm{M}$, was added to the external solution during periods indicated (cell 12/30/86-1).

inactivation measured for the inactivating $\mathrm{K}$ current of larval neurons (Solc et al., 1987) but is shifted about $30 \mathrm{mV}$ in the negative direction relative to the steady-state inactivation relation for muscle K current (Salkoff and Wyman, 1983a; Wu and Haugland, 1985; Solc et al., 1987). Thus, both steady-state inactivation and expression of the Shaker mutation distinguish the inactivating $\mathrm{K}$ current of neuron from that of muscle.

At present it appears that the Drosophila neuron somal membrane contains primarily $\mathrm{K}$ channels, while the $\mathrm{Ca}$ and $\mathrm{Na}$ channels are primarily located in the process membranes. This conclusion is reached because cell-attached patches frequently contain $\mathrm{K}$ channels but almost never contain $\mathrm{Ca}$ or $\mathrm{Na}$ channels. Also, the successful measurement of $\mathrm{K}$ reversal potentials (Fig. 5 ) and the rapid loss of $K$ currents due to exchange of intracellular $\mathrm{K}^{+}$with pipet $\mathrm{Cs}^{+}$(Fig. 4) support the idea that most of the $\mathrm{K}$ channels are in the somal membrane. In contrast, the frequent signs of escape from voltage control exhibited by the relatively small $\mathrm{Ca}$ and $\mathrm{Na}$ currents and the relatively slow washout of $\mathrm{Ca}$ currents, given the $5 \mu \mathrm{m}$ diameter of the soma (Fig. 13), support the assumption that the $\mathrm{Ca}$ and $\mathrm{Na}$ channels are in the processes. In order to obtain biophysically meaningful studies of whole-cell $\mathrm{Ca}$ and $\mathrm{Na}$ currents, techniques must be found for isolating the soma from its processes in such a way that some $\mathrm{Ca}$ or $\mathrm{Na}$ channels are incorporated into the soma. Molluscan processes round into the soma when cut a few hundred micrometers from the soma (Byerly and Hagiwara, 1982).

The whole-cell studies reported here suggest that there are multiple types of both $\mathrm{K}$ and $\mathrm{Ca}$ channels in embryonic Drosophila neurons. Single-channel studies are now needed to determine the number of different types of channels, as has been done for the $\mathrm{K}$ channels of larval neurons and embryonic myotubes (Brainard et al., 1987; Solc and Aldrich, 1988). Inactivation and sensitivity to 4-AP jointly define 2 classes of $\mathrm{K}$ channels in embryonic neurons (inactivating, 4-AP sensitive; 
Figure 15. Block of Ca current by verapamil and W7. Internal solution was enriched CsAsp; external solution, Tris Dros. saline. Holding potential was -73 $\mathrm{mV}$. Upper, Verapamil, $100 \mu \mathrm{M}$, had a weak, reversible blocking effect on the $\mathrm{Ca}$ current. Peak Ca current was measured at roughly $1 \mathrm{~min}$ intervals (cell 5/8/7-1). Lower, W7, $100 \mu \mathrm{M}$, completely blocked Ca current. Current records shown for steps to values from -53 to $+17 \mathrm{mV}$ (10 mV increments) (cell $7 / 3 / 7-26)$.
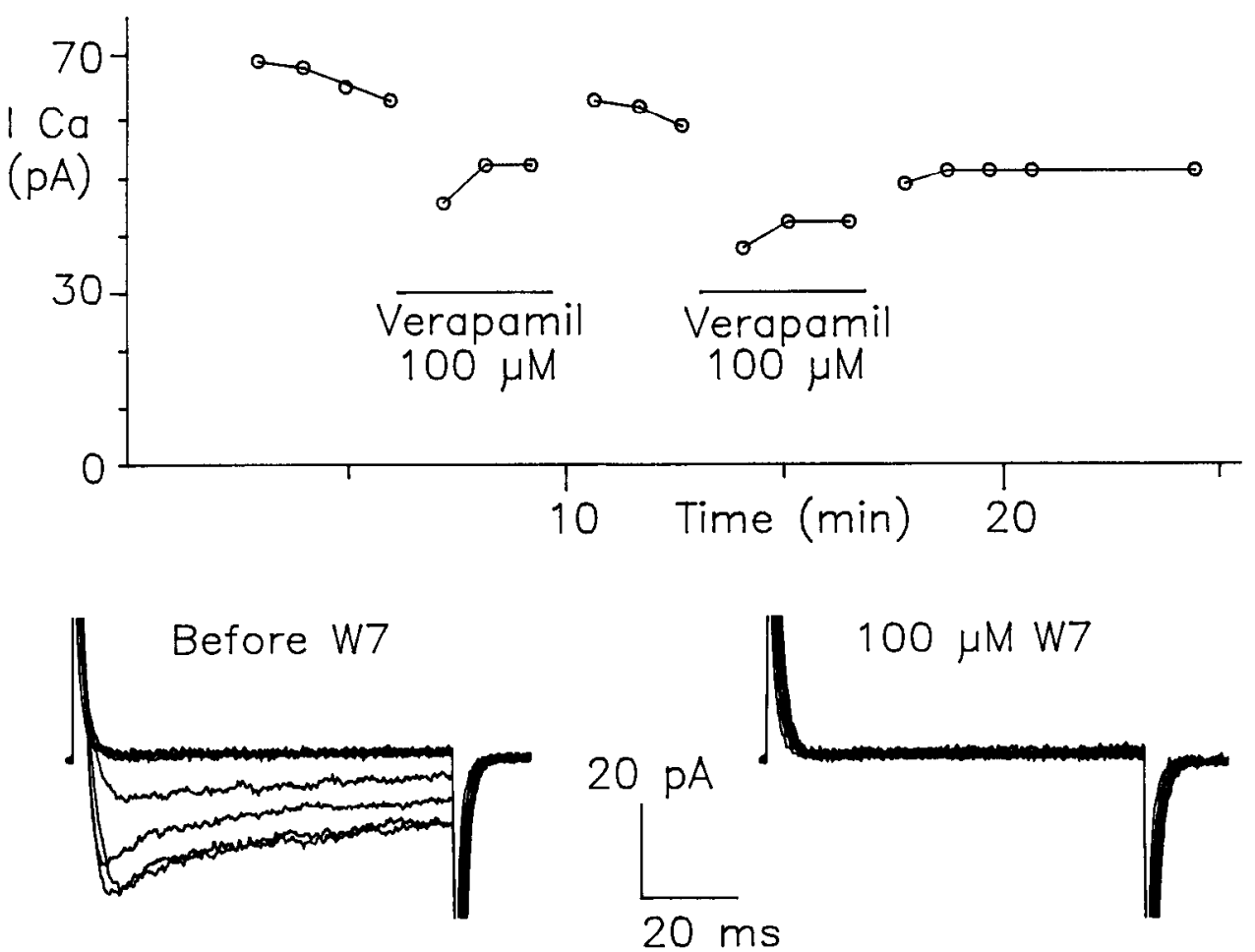

noninactivating, 4-AP insensitive), and the broad range of wholecell current inactivation rates suggests multiplc types of inactivating $\mathrm{K}$ channels. Also, preliminary patch studies reveal a variety of types of single-channel $\mathrm{K}$ currents, based on conductance and kinetics. The evidence for multiple types of $\mathrm{Ca}$ channels is not so compelling. The strongest suggestions of multiple Ca channel types come from the variable inactivation (Figs. 8, 12) and sensitivity to washout (Fig. 13) of whole-cell Ca currents. Determination of $\mathrm{Ca}$ channel types by single-channel analysis may be delayed, since we have yet to detect currents through $\mathrm{Ca}$ channels in patches.

There is a need to find highly specific antagonists (or agonists) for the Drosophila Ca channels. Not only could such agents help to distinguish different types of Ca channels, but they could allow purification of $\mathrm{Ca}$ channel proteins (Borsotto et al., 1984; Curtis and Catterall, 1984) and subsequent cloning of genes coding for these proteins (Tanabe et al., 1987). Of the Ca channel agents tested on Drosophila currents in these studies, none appears promising as a label for the $\mathrm{Ca}$ channel. Only $\mathrm{Cd}^{2+}$ and W-7 are effective blockers, but neither is highly specific. Of the organic blockers tested, only verapamil and D-600 showed any blocking effect on the Drosophila current; it is interesting that membrane extracts from Drosophila heads have been shown to contain high-affinity binding sites for verapamil and D-600 but not for dihydropyridines (Pauron et al., 1987; L. M. Hall and R. M. Greenberg, personal communication). However, since we find that verapamil has no blocking effect on the Ca current at $10 \mu \mathrm{M}$, the partial block observed at $100 \mu \mathrm{M}$ is probably nonspecific, with no relation to the high-affinity binding sites. In an effort to find specific labels for the Drosophila Ca channels, we have begun testing toxins thought to act on $\mathrm{Ca}$ channels, such as spider toxins (Bowers et al., 1987; Branton et al., 1987) omega-conotoxin (Kerr and Yoshikami, 1984), and leptinotarsin (Crosland et al., 1984).

At present, no Drosophila mutants have been isolated that are thought to specifically affect $\mathrm{Ca}$ currents. It has been suggested that the $\mathrm{Ca}$ channel is too important for mutants with altered $\mathrm{Ca}$ channels to survive. However, there may be multiple types of Ca channels, some of which might not be essential for survival. Also, it is not clear that $\mathrm{Ca}$ channels are essential to the growth of cells in culture. Thus, voltage-clamp studies of cultured neurons homozygous for lethal mutations (such as large deletions) may be useful for identifying regions of the genome that affect neuronal $\mathrm{Ca}$ currents. Conditional mutants probably offer the best chance of finding Ca channel mutants on the basis of behavior. Various laboratories are searching for new mutations that affect ionic channels by screening for temperaturesensitive paralysis, leg shaking under ether anesthesia, or resistance to verapamil-like drugs (Timpe et al., 1987; L. M. Hall and R. M. Greenberg, personal communication). Our laboratory is eager to collaborate in the analysis of any mutant that might affect the Ca current.

\section{References}

Aldrich, R. W., P. A. Getting, and S. H. Thompson (1979) Inactivation of delayed outward current in molluscan neurone somata. J. Physiol. (Lond.) 291: 507-530.

Baumann, A., I. Krah-Jentgens, R. Muller, F. Muller-Holtkamp, R. Seidel, N. Kecskemethy, J. Casal, A. Ferrus, and O. Pongs (1987) Molecular organization of the maternal effect region of the Shaker complex of Drosophila: Characterization of an $\mathrm{I}_{\mathrm{A}}$ channel transcript with homology to vertebrate $\mathrm{Na}^{+}$channel. EMBO J. 6: 3419-3429.

Bean, B. P. (1984) Nitrendipine block of cardiac calcium channels: High-affinity binding to the inactivated state. Proc. Natl. Acad. Sci. USA 81: 6388-6392.

Borsotto, M., J. Barhanin, R. I. Norman, and M. Lazdunski (1984) Purification of the dihydropyridine receptor of the voltage-dependent $\mathrm{Ca}^{2+}$ channel from skeletal muscle transverse tubules using $(+)\left[{ }^{3} \mathrm{H}\right]$ PN 200-110. Biochem. Biophys. Res. Commun. 122: 1357-1366.

Bowers, C. W., H. S. Phillips, P. Lee, Y. N. Jan, and L. Y. Jan (1987) Identification and purification of an irreversible presynaptic neurotoxin from the venom of the spider Hololena curta. Proc. Natl. Acad. Sci. USA 84: 3506-3510. 
Brainard, M. S., W. N. Zagotta, and R. W. Aldrich (1987) Four distinct potassium channels in cultured Drosophila myotubes. Soc. Neurosci. Abstr. 13: 578 .

Branton, D., L. Kolton, Y. N. Jan, and L. Y. Jan (1987) Neurotoxins from Plectreurys spider venom are potent presynaptic blockers in Drosophila. J. Neurosci. 7: 4195-4200.

Byerly, L. (1985) Voltage-dependent currents in embryonic cultures of Drosophila neurons. Soc. Neurosci. Abstr. 11: 149.

Byerly, I. (1986) Potassium, sodium and calcium currents in embryonic cultures of Drosophila neurons. Biophysical J. 49: 574a.

Byerly, L., and S. Hagiwara (1982) Calcium currents in internally perfused nerve cell bodies of Limnea stagnalis. J. Physiol. (Lond.) 322: 503-528.

Byerly, L., and S. Hagiwara (1988) Calcium channel diversity. In Calcium and Ion Channel Modulation, A. D. Grinnell, D. L. Armstrong, and M. B. Jackson, eds., pp. 3-18, Plenum, New York.

Byerly, L., and W. J. Moody (1986) Membrane currents of internally perfused neurones on the snail, Lymnaea stagnalis, at low intracellular pH. J. Physiol. (Lond.) 376: 477-491.

Corey, D. P., and C. F. Stevens (1983) Science and technology of patch-recording electrodes. In Single-Channel Recording, B. Sakmann and E. Neher, eds., pp. 53-68, Plenum, New York.

Crosland, R. D., T. H. Hsiao, and W. O. McClure (1984) Purification and characterization of $\beta$-leptinotarsin-h, an activation of presynaptic neurotoxin. Biochemistry 23: 734-741.

Curtis, B. M., and W. A. Catterall (1984) Purification of the calcium antagonist receptor of the voltage-sensitive calcium channel from skeletal muscle transverse tubules. Biochemistry 23: 2113-2118.

Eckert, R., and J. Chad (1984) Inactivation of Ca channels. Prog. Biophys. Mol. Biol. 44: 215-267.

Ehrlich, B. E., M. Forte, A. R. Jacobson, and L. M. Sayre (1987) Block of Paramecium calcium channels by the calmodulin antagonist W-7 and its analogues. Biophys. J. 51: 31 a.

Fenwick, E. M., A. Marty, and E. Neher (1982) Sodium and calcium channels in bovine chromaffin cells. J. Physiol. (Lond.) 331: 599635.

Ganetzky, B., and C.-F. Wu (1983) Neurogenetic analysis of potassium currents in Drosophila: Synergistic effects on neuromuscular transmission in double mutants. J. Neurogenet. 1: 17-28.

Ganetzky, B., and C.-F. Wu (1985) Genes and membrane excitability in Drosophila. TINS 8: 322-326.

Ganitkevich, V. Y., M. F. Shuba, and S. V. Smirnov (1986) Potentialdependent calcium inward current in a single isolated smooth muscle cell of the guinea-pig Taenia caeci. J. Physiol. (Lond.) 380: 1-16.

Geduldig, D., and D. Junge (1968) Sodium and calcium components of action potentials in the Aplysia giant neurone. J. Physiol. (Lond.) 199: 347-365.

Hagiwara, S., and L. Byerly (1981) Calcium channel. Annu. Rev. Neurosci. 4: 69-125.

Hagiwara, S., and H. Ohmori (1982) Studies of calcium channels in rat clonal pituitary cells with patch electrode voltage clamp. J. Physiol. (Lond.) 331: 231-252.

Hamill, O. P., A. Marty, E. Neher, B. Sakmann, and F. J. Sigworth (1981) Improved patch-clamp techniques for high-resolution current recording from cells and cell-free membrane patches. Pfluegers Arch. 391: 85-100.

Hess, P., J. B. Lansman, and R. W. Tsien (1984) Different modes of Ca channel gating behaviour favoured by dihydropyridine Ca agonists and antagonists. Nature 311: 538-544.

Hille, B. (1984) Ionic Channels of Excitable Membranes, Sinauer, Sunderland, MA.

Holton, T., and A. J. Hudspeth (1986) The transduction channel of hair cells from the bull-frog characterized by noise analysis. J. Physiol. (Lond.) 375: 195-227.

Jan, L. Y., and Y. N. Jan (1976) Properties of the larval neuromuscular junction in Drosophila melanogaster. J. Physiol. (Lond.) 262: 189214.

Jan, L. Y., D. M. Papazian, L. Timpe, P. O'Farrell, and Y. N. Jan (1985) Application of Drosophila molecular genetics in the study of neural function-Studies of the shaker locus for a potassium channel. TINS 8: 234-238.

Janis, R. A., D. Rampe, C. M. Su, and D. J. Triggle (1985) $\mathrm{Ca}^{2+}$ channel: Ligand-induced antagonism and activation. In Calcium Entry Blockers and Tissue Protection, T. Godfraind, P. M. Vanhoutte, S. Govoni, and R. Paoletti. eds., pp. 21-30, Raven, New York.
Kamb, A., L. E. Iverson, and M. A. Tanouye (1987) Molecular characterization of shaker, a Drosophila gene that encodes a potassium channel. Cell 50: 405-413.

Kerr, L. M., and D. Yoshikami (1984) A venom peptide with a novel presynaptic blocking action. Nature 308: 282-284.

Kostyuk, P. G., N. S. Veselovsky, and S. A. Fedulova (1981) Ionic currents in the somatic membrane of rat dorsal root ganglion neurons-II. Calcium currents. Neuroscience 6: 2431-2437.

I ee, K. S., and R. W. Tsien (1983) Mechanism of calcium channel blockade by verapamil, D600, diltiazem and nitrendipine in single dialysed heart cells. Nature 302: 790-794.

Leung, H.-T., and L. Byerly (1987) Calcium currents in embryonic cultures of Drosophila neurons. Soc. Neurosci. Abstr. 13: 101.

Meech, R. W. (1986) Membranes, gates, and channels. In The Mollusca 9, pp. 189-277, Academic, Orlando, FL.

Nilius, B., P. Hess, J. B. Lansman, and R. W. Tsien (1985) A novel type of cardiac calcium channel in ventricular cells. Nature 316:443446.

Papazian, D. M., T. L. Schwarz, B. L. Tempel, Y. N. Jan, and L. Y. Jan (1987) Cloning of genomic and complementary DNA from shaker, a putative potassium channel gene from Drosophila. Science 237: 749-753.

Pauron, D., J. Qar, J. Barhanin, D. Fournier, A. Cuany, M. Pralavorio, J. B. Berge, and M. Lazdunski (1987) Identification and affinity labeling of very high affinity binding sites for the phenylalkylamine series of $\mathrm{Ca}^{+}$channel blockers in the Drosophila nervous system. Biochemistry 26: 6311-6315.

Salkoff, L. (1985) Development of ion channels in the flight muscles of Drosophila. J. Physiol. (Paris) 80: 275-282.

Salkoff, L. B., and M. A. Tanouye (1986) Genetics of ion channels. Physiol. Rev, 66: 301-329.

Salkoff, L. B., and R. Wyman (1981) Genetic modification of potassium channels in Drosophila shaker mutants. Nature 293: 228-230.

Salkoff, L. B., and R. J. Wyman (1983a) Ion currents in Drosophila flight muscles. J. Physiol. (Lond.) 337: 687-709.

Salkoff, L., and R. Wyman (1983b) Ion channels in Drosophila muscle. TINS 6: 128-133.

Salvaterra, P. M., N. Bournias-Vardiabasis, T. Nair, G. Hou, and C. Lieu (1987) In vitro neuronal differentiation of Drosophila embryo cells. J. Neurosci. 7: 10-22.

Seecof, R. L., and R. L. Unanue (1968) Differentiation of embryonic Drosophila cells in vitro. Exp. Cell Res. 50:654-660.

Seecof, R. L., N. Alleaume, R. L. Teplitz, and I. Gerson (1971) Differentiation of neurons and myocytes in cell cultures made from Drosophila gastrulae. Exp. Cell Res. 69: 161-173.

Seecof, R. L., J. J. Donady, and R. L. Teplitz (1973) Differentiation of Drosophila neuroblasts to form ganglion-like clusters of neurons in vitro. Cell Differ. 2: 143-149.

Solc, C. K., and R. W. Aldrich (1988) Voltage-gated potassium channels in larval CNS neurons of Drosophila. J. Neurosci. 8: 2556-2570.

Solc, C. K., W. N. Zagotta, and R. W. Aldrich (1987) Single-channel and genetic analyses reveal two distinct A-type potassium channels in Drosophila. Science 236: 1094-1098.

Tanabe, T., H. Takeshima, A. Mikami, V. Flockerzi, H. Takahashi, K. Kangawa, M. Kojima, H. Matsuo, T. Hirose, and S. Numa (1987) Primary structure of the receptor for calcium channel blockers from skeletal muscle. Nature 328: 313-318.

Thompson, S. H. (1977) Three pharmacologically distinct potassium channels in molluscan neurones. J. Physiol. (Lond.) 265: 465-488.

Timpe, L. C., and L. Y. Jan (1987) Gene dosage and complementation analysis of the Shaker Locus in Drosophila. J. Neurosci. 7: 13071317.

Timpe, L. C., W. Moats, Y. N. Jan, and L. Y. Jan (1987) A new behavioral mutant in Drosophila melanogaster, with a phenotype of neuronal hyperexcitability. Soc. Neurosci. Abstr. 13: 578.

Wei, A., and L. Salkoff (1986) Occult Drosophila calcium channels and twinning of calcium and voltage-activated potassium channels. Science 233: 780-782.

Wu, C.-F., and F. N. Haugland (1985) Voltage clamp analysis of membrane currents in larval muscle fibers of Drosophila: Alteration of potassium currents in shaker mutants. J. Neurosci. 5: 2626-2640.

Wu, C.-F., N. Suzuki, and M.-M. Poo (1983) Dissociated neurons from normal and mutant Drosophila larval central nervous system in cell culture. J. Neurosci. 3: 1888-1899. 